\title{
Radnici na minimalnoj plaći i siromaštvo u Hrvatskoj
}

DANIJEL NESTIĆ*

Ekonomski institut, Zagreb

Zagreb, Hrvatska

\section{SANJA BLAŽEVIĆ BURIĆ}

Fakultet ekonomije i turizma „Dr. Mijo Mirković“

Sveučilište Jurja Dobrile u Puli

Pula, Hrvatska
Izvorni znanstveni rad

UDK: 331.215:364.65-058.34(497.5)

doi: $10.3935 /$ rsp.v25i3.1547

Primljeno: travanj 2018.

U radu se prikazuju osnovne socio-ekonomske karakteristike primatelja minimalne plaće u Hrvatskoj, procjenjuje se materijalno stanje i siromaštvo njihovih kućanstava te simuliraju učinci rasta minimalne plaće na siromaštvo $i$ nejednakost. Rezultati se temelje na analizi podataka Ankete o radnoj snazi (ARS) $i$ Ankete o dohotku stanovništva (ADS). Podaci ARS-a za razdoblje između 2007. i 2014. ukazuju na postupni porast broja primatelja minimalne plaće, posebno među mlađim $i$ visokoobrazovanim radnicima, ali $i$ na smanjenje udjela žena. Djelatnosti s najvećom raširenošću isplata minimalne plaće su prerađivačka industrija, trgovina na veliko i malo, građevinarstvo $i$ djelatnosti pružanja smještaja te pripreme i usluživanje hrane. Podaci ADS-a pokazuju da je siromaštvo među primateljima minimalne plaće manje od prosjeka za ukupno stanovništvo Hrvatske. Tek nešto više od 1\% svih siromašnih su primatelji minimalne plaće. Simulacija rasta minimalne plaće pokazuje ograničen učinak na siromaštvo i dohodovnu nejednakost.

Ključne riječi: minimalna plaća, primatelji minimalne plaće, siromaštvo, Hrvatska.

${ }^{*}$ Danijel Nestić, Ekonomski institut, Zagreb / The Institute of Economics, Zagreb, Trg J. F. Kennedyja 7, 10000 Zagreb, Hrvatska / Croatia, dnestic@eizg.hr 


\section{UVOD}

Minimalna je plaća sve rašireniji oblik regulacije tržišta rada kojom se nastoje ispraviti tržišne nepravilnosti. Neravnoteža u pregovaračkoj moći radnika i poslodavaca može dovesti do ekstremno niskih plaća, odnosno do stanja pri kojem su plaće radnika s najnižim plaćama neopravdano značajno ispod njihove granične proizvodnosti. Onemogućavanje takvih situacija je temeljni razlog zakonskog zahvata u ugovorne odnose između radnika i poslodavca. Iako je procjena granične proizvodnosti gotovo nemoguća za praktične svrhe, u društvu se s vremenom razvilo saznanje o određenoj granici plaće koja se smatra najnižom prihvatljivom cijenom rada kojom se može izbjeći eksploatacija slabog tržišnog položaja radnika. Međutim, i ciljevi i očekivanja i učinci minimalne plaće u suvremenom društvu daleko su širi od navedenog temeljnog motiva zakonskog određivanja minimalne cijena rada.

Ključni dionici na tržištu rada imaju različite i često suprotstavljene zahtjeve od politike minimalne plaće. Sindikati će se zalagati za minimalnu plaću koja omogućava primjeren životni standard primateljima i njihovim obiteljima. Nerijetko će navoditi i borbu protiv siromaštva kao argument za aktivnu politiku minimalne plaće. Poslodavci na minimalnu plaću često gledaju kao na nametnutu nužnost, a od politike minimalne plaće očekuju da vodi računa o potencijalno negativnim posljedicama za poslovanje, poput smanjene profitabilnosti i konkurentnosti zbog rasta troškova rada. Država, osim kao zakonodavac, ima i svoje izvorne interese oko politike minimalne plaće. Kratkoročni politički interesi upućuju da je popularno donositi odluke o povećanju minimalne plaće, a kratkoročni ekonomski interesi ukazuju da rast minimalne plaće može donijeti veće porezne prihode $\mathrm{i}$ manje socijalne izdatke. No, s druge strane stoji dugoročni interes za snažnim gospodarstvom i rastom životnog standarda svih građana. Takav interes nalaže oprezniju politiku minimalne plaće usmjerenu na jačanje njezinih pozitivnih i izbjegavanje ili minimiziranje negativnih učinaka.

Stručna literatura iz područja tržišta rada ekstenzivno se bavila minimalnom plaćom i ukazala na njezine moguće učinke. Pokazalo se ipak da ne postoje jasni opći učinci, već oni ključno ovise o nacionalnom kontekstu, a mogu biti različiti za različite skupine zaposlenika. Stoga je važno poznavati strukturu primatelja minimalne plaće u pojedinom gospodarstvu kako bi se bolje mogli ocijeniti učinci eventualnih promjena u politici minimalne plaće, kao i mogućnosti zadovoljavanja javno izraženih interesa socijalnih partnera. Za Hrvatsku postoje osnovne informacije o socio-ekonomskim karakteristikama samih primatelja minimalne plaće za 2000-te (Nestić, 2010.; Nestić i Rašić Bakarić, 2010.; Mrnjavac i Blažević, 2014.). Za novije razdoblje nije bilo objavljenih radova. Osim toga, dosadašnja su istraživanja bila fokusirana na primatelje minimalne plaće, a materijalno stanje kućanstava u kojima su živjeli nije bilo obuhvaćeno analizom. Stoga ovaj rad u empirijskome dijelu ima za cilj prezentirati širi skup pokazatelja o primateljima minimalne plaće i to temeljem dviju anketa. Podacima iz Ankete o radnoj snazi (ARS) ažurirat će se saznanja o socio-ekonomskim karakteristikama primatelja minimalne plaće (obrazovanje, dob, spol, staž, tip ugovora o radu) i razmotriti promjene koje su se dogodile između 2007. i 2014., dok će se na temelju Ankete o dohotku stanovništva (ADS) analizirati materijalno stanje i raširenost siromaštva u kućanstvima primatelja minimalne plaće. Ova su saznanja važna jer se na temelju njih mogu oblikovati informirana očekivanja o učincima povećanja minimal- 
ne place na različite skupine stanovništva. Kako bi se to ilustriralo, u radu je na temelju podataka ADS-a i određenog broja pretpostavki pripremljena simulacija učinaka rasta razine minimalne plaće na siromaštvo i nejednakost.

Rad je organiziran na sljedeći način. U drugom se poglavlju nalazi pregled istraživanja o učincima minimalne plaće u svijetu, a u trećem poglavlju pregled za Hrvatsku. U četvrtom su poglavlju prikazane osnovne informacije o sustavu minimalne plaće u Hrvatskoj. U petom se poglavlju analiziraju promjene $\mathrm{u}$ profilu primatelja minimalne plaće između 2007. i 2014. temeljem podataka Ankete o radnoj snazi. U šestom je poglavlju analiza profila primatelja minimalne plaće nadopunjena informacijama iz Ankete o dohotku stanovništva za razdoblje 2012.-2014. o raspoloživom dohotku i siromaštvu njihovih kućanstava U sedmom su poglavlju prikazani rezultati simulacije učinaka rasta minimalne plaća na nejednakost i siromaštvo. Zaključci rada nalaze se u osmom poglavlju.

\section{PREGLED NOVIJIH ISTRAŽIVANJA UČINAKA MINIMALNE PLAĆE}

Istraživanje učinaka minimalne plaće jedno je od najčešće razmatranih pitanja u ekonomiji rada, s raspravom dužom od 150 godina. Ključni radovi, a koji ujedno pružaju i dobar pregled povijesti istraživanja, uključuju Brown i sur., 1982.; Card i Krueger, 1994.; Neumark i Wascher, 2006, 2008.; Addison i sur., 2009.; Dube i sur., 2010.; Allegretto i sur., 2013.; Giuliano, 2013. Usprkos brojnim istraživanjima, čini se da se ne mogu izvesti čvrsti opći zaključci o učincima niti u teorijskom niti u empirijskom pogledu. Dok jedne studije, često na bazi panel podataka, pronalaze negativnu i signifikantnu vezu između mini- malne plaće i zaposlenosti (npr. Neumark i Wascher, 1992.), drugi radovi, uglavnom bazirani na studijama slučajeva, nalaze pozitivnu vezu (npr. Card i Krueger, 1994.). Metodološka pitanja izolacije učinka minimalne plaće od drugih povezanih čimbenika još su uvijek otvorena. Minimalna plaća tek je jedan instrument koji utječe na kretanja na tržištu rada djelujući u kompleksnom makroekonomskom okruženju zbog čega je teško izdvojiti utjecaj minimalne plaće na zaposlenost, proizvodnost i životni standard.

Osim samostalnih istraživanja, do čvršćih saznanja pokušalo se doći metastudijama, odnosno ponovnim pregledom najutjecajnijih postojećih radova. Tako su Neumark i Wascher (2006.) na temelju analize 33 prethodne studije došli do zaključka o statistički značajnom negativnom utjecaju minimalne plaće na zaposlenost. No, i taj je rezultat doživio osporavanja. Doucouliagos i Stanley (2009.) su temeljem rezultata metaanalize na uzorku 64 američka istraživanja zaključili da u literaturi, odnosno među urednicima časopisa postoji značajna pristranost prema odabiru radova u kojima se potvrđuje teza o negativnoj vezi minimalne plaće i odabranih socio-ekonomskih varijabli. Eliminiranjem te pristranosti nisu uočili postojanje negativne veze između minimalne plaće i najčešće istraživane varijable, zaposlenosti. Wolfson i Belman (2014.) proveli su metaanalizu na temelju 27 istraživanja i više od 200 procjena učinaka minimalne plaće na zaposlenost, te zaključili da nema negativnog utjecaja na zaposlenost. Kod pojedinih istraživanja koja nisu pronašla značajan učinak na zaposlenost (npr. Bruttel i sur., 2017.; Heise, 2017.) ukazuje se na kompenzaciju drugim učincima, poput smanjivanja sati rada, povećanja intenziteta rada ili povećanja cijena.

U novije se vrijeme pojavljuju i prve procjene učinaka uvođenja minimalne pla- 
će u Njemačkoj, što je analitički izuzetno zanimljiv slučaj. Caliendo i sur. (2017.) nisu pronašli izraženiji signifikantan učinak na regularnu zaposlenost. No, pronašli su mali, ali signifikantan pad zaposlenosti kod marginalnih tipova zaposlenja, ponajviše kod takozvanih mini-poslova. Burauel i sur. (2017.) ukazuju da je uvođenje minimalne plaće znatno povećalo plaće na donjem kraju distribucije plaća, ali i da značajan dio zaposlenika još uvijek zarađuje manje od minimalne plaće. Učinak na rast primanja radnika na donjem kraju distribucije osjetno se razlikuje po skupinama zanimanja, tipu ugovora o radu, dobi, spolu i veličini poduzeća, što još jednom ukazuje na važnost informacija o radnicima koji primaju minimalnu plaću ili plaću blizu minimalne plaća za ocjenu mogućih učinaka.

\section{ISTRAŽIVANJA O UČINCIMA MINIMALNE PLAĆE U HRVATSKOJ}

U Hrvatskoj se pitanje minimalne plaće nije istraživalo u značajnijem obujmu. Ipak, posljednjih nekoliko godina raste interes za ovu temu. On se može posebno prepoznati u dva područja s obzirom na aspekt promatranja - pravnom i ekonomskom.

Iz pravne perspektive analizirali su se sadržaj Zakona o minimalnoj plaći i specifične teme iz djelokruga Zakona. Tako, primjerice, Carević i sur. (2008.) razmatraju primjenu isplate minimalne plaće za strance upućene na rad u Hrvatsku (eng. posted workers), što Zakonom o minimalnoj plaći iz 2008. godine, kada je članak objavljen, nije bilo izričito propisano. Rožman (2009.) se osvrnuo na dvojbe u načinu utvrđivanja minimalne plaće za 2009. godinu. Grgurev i Vukorepa (2013.) obrađivale su pravne aspekte Zakona o minimalnoj plaći, ali i širu funkciju minimalne plaće u kontekstu siromaštva, dostojanstva radnika i instituta kolektivnog pregovaranja. Zaključuju da je zbog relativno niske stope sindikaliziranosti, niske sektorske pokrivenosti kolektivnim ugovorima i nepostojanja tradicije socijalnog dijaloga u Hrvatskoj bilo potrebno zakonom, na nacionalnoj razini, odrediti visinu i obuhvat minimalne plaće,

Ekonomske aspekte Zakona o minimalnoj plaći iz 2008. razmatrao je Nestić (2009.), s posebnim osvrtom na formulu godišnjeg usklađivanja visine minimalne plaće. Smatrao je da kod usklađivanja minimalne plaće treba uzeti u obzir očekivane buduće vrijednosti ključnih parametara, a ne njihova dotadašnja kretanja. Zato je predložio je da se napusti određivanje visine minimalne plaće putem rigidne formule, već da se ona određuje dijalogom socijalnih partnera. Nestić (2010.) je razmatrao moguće učinke minimalne plaće u Hrvatskoj na siromaštvo radnika, disparitete plaća, zaposlenost, kolektivno pregovaranje i mobilnosti u EU (strane investicije, mobilnost rad, te proizvoda i usluga). U većini slučajeva smatra da su učinci bili mali zbog niskog obuhvata minimalnom plaćom koji je, na temelju podataka Ankete o radnoj snazi, procijenio na $3 \%$ zaposlenih. Anketni podaci pokazali su da se najčešće radilo o ženama, slabije obrazovanim osobama, mlađima, zaposlenima na ugovor na određeno vrijeme, zaposlenima u manjim poduzećima i u poduzećima $u$ privatnom vlasništvu. Nestić i Rašić Bakarić (2010.) istraživali su međuodnos između minimalne plaće i sustava kolektivnog pregovaranju u Hrvatskoj. Posebno su razmotrili stanje u sektorima građevinarstva, tekstilne industrije i trgovine, te $\mathrm{u}$ izabranim poduzećima iz tih sektora. Zaključili su kako je struktura tržišta imala ključnu ulogu u značajnim opaženim razlikama u stanju kolektivnih pregovora u tim sektorima. Iako su socijalni partneri koje su intervjuirali smatrali da normiranje minimalne 
plaće u zakonu nije utjecalo na kolektivne pregovore, uočeno je da kolektivni ugovori općenito dodaju vrlo malo dodatnih prava ili prednosti u odnosu na Zakon o radu i Zakon o minimalnoj plaći. Takvo se stanje objašnjava nedostatkom povjerenja među socijalnim partnerima, te većim uspjehom sindikata $\mathrm{u}$ postizanju svojih ciljeva $\mathrm{kroz}$ lobiranje za promjene zakona nego kroz izravne pregovore s poslodavcima. Određivanje najniže cijene rada smatraju samo dijelom te šire priče. U tom su radu Nestić i Rašić Bakarić na temelju Ankete o radnoj snazi procijenili obuhvat minimalne plaće 1998., 2005. i 2008. godine, pri čemu nalaze da je on povećan s 3\% u 1998. i 2005. na $8 \%$ u 2008. godini nakon donošenja Zakona o minimalnoj plaći. Isto tako, pokazuju i profil primatelja minimalne plaće u 2008., koji se nije značajnije promijenio u odnosu na stanje iz 2005. koje je opisao Nestić (2010.).

Utjecaj minimalne plaće na stopu zaposlenosti, sate rada i prosječnu/medijalnu plaću po različitim skupinama radnika $\mathrm{s}$ obzirom na spol, dob i razinu obrazovanja istraživala je Blažević (2012.) u doktorskoj disertaciji koristeći podatke Ankete o radnoj snazi. Potvrđena je pretpostavka o ograničenom dotadašnjem utjecaju minimalne plaće na zaposlenost, a čak se utvrdio i pozitivan utjecaj na agregatnoj razini, no praktične vrijednosti bile su zanemarive. Dokazano je i postojanje efekta $\gg$ mreškanja«, odnosno prenošenje povećanja minimalne plaće na ostale plaće što znači da koristi od rasta minimalne plaće mogu imati i radnici iz višeg dijela distribucije plaća, pri čemu se izbjegava kompresija distribucije plaća i dolazi do porasta cijele skale plaća. Mrnjavac i Blažević (2014.) analizirali su profil primatelja minimalne plaće od 2000. do 2010. godine, pri čemu posebno promatraju skupinu radnika koji primaju plaću osjetno ispod razine minimalne pla- će. Pronašli su da su primatelji minimalne plaće većinom žene s nižom razinom obrazovanja, da borave u ruralnim područjima i većinom su zaposlene kod poslodavaca u privatnom sektoru. Radnici koji primaju plaću znatno ispod razine minimalne plaće su mahom poljoprivredni radnici, rade nepuno radno vrijeme i također je većinom riječ o ženama. U kontekstu siromaštva, zaključili su da minimalna plaća do 2010. nije doprinijela smanjenju siromaštva radnika te su predloženi alternativni instrumenti koji bi, očekuju, bili efikasniji alat u borbi protiv siromaštva. To su porezna rasterećenja, programi pomoći za poslodavce ili programi pomoći za radnike.

Komparativnu analizu minimalne plaće u Hrvatskoj i izabranim zemljama EU-a kroz njezin odnos sa sustavom kolektivnog pregovaranja $\mathrm{u}$ sektorima trgovine i građevinarstva pripremili su Banyuls i sur. (2013.) te Bosch i sur. (2013.). Za Hrvatsku je uočena bitna razlika između ta dva sektora u kontekstu učinka povećanja minimalne plaće s obzirom na postojeće sektorske kolektivne ugovore $\mathrm{s}$ proširenom primjenom. Naime, u sektoru trgovine na snazi je bio sektorski kolektivni ugovor prema kojemu je najniža plaća bila određena na razini ispod minimalne plaće $i$ na tu ugovorenu razinu vezuje se sustav koeficijenata za različita zanimanja. Zbog takvog kolektivnog ugovora povećanje minimalne plaće nije utjecalo na cijelu distribuciju plaća, već samo na najslabije plaćene radnike (Banyuls i sur., 2013.). S druge strane, u sektoru graditeljstva je do 2013. na snazi bio kolektivni ugovor kojim je najniža osnovna plaća određena na razini nacionalne minimalne plaće, a na nju su onda vezani koeficijenti za druga radna mjesta. Zbog toga je povećanje minimalne plaće automatski dovelo do povećanja plaća za sve tarifne razrede u sektoru graditeljstva (Bosch i sur., 2013.). 
Nestić i sur. (2018.) istraživali su važnost minimalne plaće za pojedine djelatnosti i regije u Hrvatskoj na temelju ankete poslodavaca koju provodi Državni zavod za statistiku. Identificirali su 13 sektora i 5 županija s visokim udjelom niskoplaćenih radnih mjesta zbog čega su oni najizloženiji učincima promjena minimalne plaće. Kod sektora, radi se o industriji tekstila i odjeće, industriji kože i obuće, drvnoj industriji, proizvodnji gume i plastike, industriji namještaja, gradnja zgrada, specijaliziranoj građevinskoj djelatnosti, maloprodaji, ugostiteljskim uslugama, zaštitarskoj djelatnosti, osobnim uslugama i uslugama održavanja zgrada (čišćenje i slično). Analizirali su kretanje plaća i zaposlenosti u ovim sektorima u razdoblju 2009.-2015. gdje se pokazalo se da su promjene minimalne plaće zbog visokog udjela slabo plaćenih radnih mjesta najviše utjecale na sektore koji većinom proizvode za izvoz, a ujedno su izloženi konkurenciji iz uvoza, dok su manje bili pogođeni uslužni lokalni sektori. U nekim od sektora (proizvodnja odjeće, čišćenje zgrada, osobne usluge), minimalnu plaću prima gotovo četvrtina zaposlenih, dok je nacionalni prosjek za Hrvatsku procijenjen na nešto preko 5\% u 2015.

\section{SUSTAV MINIMALNE PLAĆE U HRVATSKOJ}

Premda je prvi Zakon o minimalnoj plaći donesen tek sredinom 2008. godine, obvezujuća minimalna plaća za sve zaposlenike u Hrvatskoj de facto postoji od 1998. Tako je 6. ožujka 1998. godine potpisan Kolektivni ugovor o visini najniže plaće između Vlade i Udruge poslodavaca obrtnika, malih i srednjih poduzetnika, štedno kreditnih zadruga i stranih predstavništava Hrvatske na strani poslodavaca te Saveza samostalnih sindikata Hrvatske i Matice hrvatskih sindikata javnih službi na strani sindikata. Istog je dana Vlada donijela $O d$ luku o proširenju Kolektivnog ugovora o visini najniže plaće čime je sam kolektivni ugovor, a time i njime određena minimalna plaća, postao obvezan u primjeni za sve zaposlenike na području Republike Hrvatske. Sam Kolektivni ugovor o visini najniže plaće utvrđuje da plaća u bruto iznosu ne može biti niža od najniže osnovice za plaćanje doprinosa za socijalna osiguranja utvrđene posebnim propisima. Visinu osnovice određivao je ministar financija, najprije samostalno, a od 2003. godine ona je uređena tako da iznosi $35 \%$ prosječne bruto plaće za prvih osam mjeseci prethodne godine.

Zakonsko uređenje minimalne plaće uspostavljeno je u srpnju 2008. Definicija minimalne plaće u Zakonu o minimalnoj plaći ostala je jednostavna; minimalna plaća je najniži mjesečni iznos bruto plaće koji pripada radniku za rad u punom radnom vremenu. Zakon je odredio novu početnu razinu minimalne plaće od 2747 kuna. U prijelaznom razdoblju od četiri godine bila je dopuštena isplata plaće niže od minimalne u tekstilnoj, drvnoprerađivačkoj i kožarsko-obućarskoj industriji (6\% u prvoj, 4\% u drugoj, 3\% u trećoj i 2\% u četvrtoj godini primjene zakona). Zakonom su bili propisani pokazatelji pomoću kojih će se jednom godišnje ažurirati visina minimalne plaće (kretanje plaća i BDP-a), a jasno su propisane i kazne za nepoštovanje obveze isplate minimalne plaće. Zakonom je pravno bitno osnažen sustav minimalne plaće u odnosu na prethodno stanje temeljeno na proširenoj primjeni kolektivnog ugovora.

U provedbi su se zakona iz 2008. vrlo brzo pojavile poteškoće vezane uz definiciju djelatnosti poslodavaca koji imaju pravo na sniženu minimalnu plaća, te ponajviše one vezane uz redovito godišnje usklađivanje minimalne plaće. Vlada i sindikati različito su tumačili odredbu koja to pro- 
pisuje već kod prvog usklađivanja u lipnju 2009., pri čemu je Vlada propisala manji rast minimalne plaće od očekivanja sindikata. S obzirom na tadašnji snažan utjecaj globalne recesije na hrvatsko gospodarstvo ipak nije došlo do veće konfrontacije. Sindikati su bili svjesni da u takvoj situaciji nije realno očekivati značajniji rast minimalne plaće, ali su i oni i drugi socijalni partneri postali svjesni potrebe jasnijeg definiranja minimalne plaće. ${ }^{1}$ To se pokušalo riješiti novim Zakonom o minimalnoj plaći iz 2013. godini. Njime je određena nova, nešto viša, početna razina minimalne plaće temeljem formule koja je uključivala prag rizika od siromaštva za jednočlano kućanstvo, prosječnu veličinu kućanstva i stopu aktivnosti. Određeno je da će se usklađivanje minimalne plaće vršiti početkom svake godine temeljem odluke Vlade koja će se donijeti na preporuku ministra nadležnog za rad nakon konzultacija sa socijalnim partnerimate »imajući u vidu povećanje udjela minimalne plaće u prosječnoj plaći«.

Izmjenama Zakona o minimalnoj plaći koje su stupile na snagu početkom 2018. godine precizirano je da je minimalna plaća naknada za redovan rad, dok se prekovremeni rad, noćni rad i rad nedjeljom, blagdanom ili nekim drugim zakonom određenim neradnim danom trebaju platiti povrh minimalne plaće. Važna izmjena odnosi se na smanjenje doprinosa na plaće za $50 \%$ za sve radnike koji su minimalnu plaću primali najmanje u prethodnih dvanaest mjeseci. Učinci ove posljednje, potencijalno ekonomski značajne i analitički vrlo intrigantne promjene tek se trebaju istražiti.

Kretanje visine minimalne plaće bilo je pod snažnim utjecajem regulatornog okvira, pri čemu je prilikom donošenja $\mathrm{Za}-$ kona o minimalnoj plaći 2008., te potom 2013. došlo do većeg jednokratnog rasta temeljem novih početnih razina (Slika 1.). Upravo su ovi skokovi razine posebno zanimljivi za istraživanje i zato se u ovome radu analiziraju podaci iz Ankete o radnoj snazi i Ankete o dohotku stanovništva koji obuhvaćaju oba ili bar jedan od ovih skokova kako bi se obuhvatili njihovi učinci.

Nominalni je iznos minimalne plaće u Hrvatskoj kontinuirano rastao od 1998. godine da bi u 2018. godinu dosegao razinu od 3 439,80 kuna bruto, što odgovara iznosu neto plaće od 2 751,84 kuna. Udio minimalne bruto plaće u prosječnoj bruto plaći 1998. godine iznosio je 33,2\%, 2017. godine $32,6 \%$, nakon rasta minimalne plaće 2008. on bio povećan na $36,5 \%$ u 2009 ., da bi do 2012. pao na 35,7\%, a nakon implementacije novog zakona iz 2013., taj je udio u 2014 povećan na $37,9 \%$, a podaci za 2017. godinu pokazuju omjer od 40,7\%. Što se tiče kretanja minimalne plaće u realnim terminima, ona je uglavnom rasla tijekom cijelog razdoblja primjene, premda je gospodarska kriza godine utjecala najprije na usporavanje rasta u 2009. a potom i pad realne minimalne plaće od 2010. do 2012. godine. Od 2013. do 2017. je minimalna plaća ponovno rasla u realnim terminima, nadoknadivši time pad iz razdoblja recesije. Ona je 2017. bila realno 7,3\% veća nego 2008. godine.

Procjena broja primatelja minimalne plaće u Hrvatskoj ovisi o izvoru podataka, obuhvatu zaposlenosti i definiciji primatelja minimalne plaće. Nestić i sur. (2018.) su na temelju podataka Državnog zavoda za statistiku o raspodjeli zaposlenika prema visini neto plaće u 2015. godini procijenili da je tada $5,4 \%$ radnika u pravnim osobama koji su radili puno radno vrijeme primalo minimalnu plaću. Točnije, toliki je bio udio radnika koji su primali neto plaću nižu od 2500 kuna, što je tada bilo 103\% minimal-

\footnotetext{
${ }^{1}$ O tome nešto više vidjeti u Rožman (2009.) i Nestić (2009., 2010.).
} 
Slika 1.

Stope rasta prosječne bruto plaće i minimalne plaće (realno)

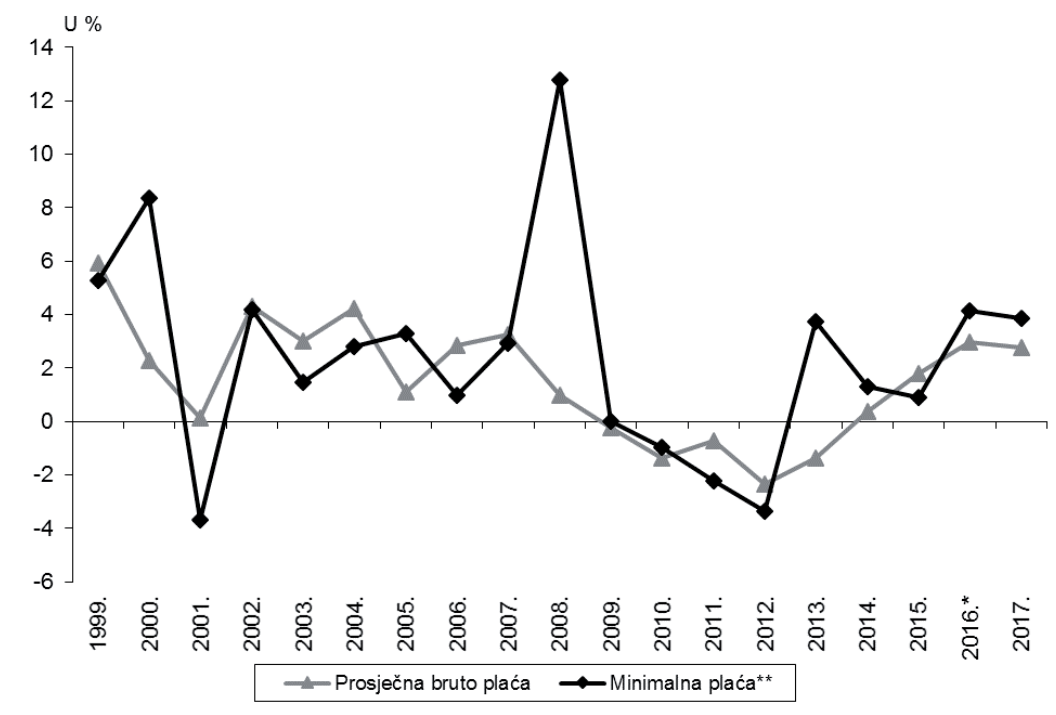

Napomene: * Od 2016. godine službeni statistički pokazatelji prosječnih plaća baziraju se na poreznom obrascu (JOPPD), za razliku od ranijih podataka na temelju ankete poduzeća. ** Prema iznosu minimalne plaće 1. srpnja određene godine.

Izvor: Državni zavod za statistiku i izračuni autora.

ne plaće izražene u neto iznosu. Eurostat (2018.) je na temelju Ankete o strukturi zarada za 2014. godinu za Hrvatsku procijenio da 7,6\% zaposlenika koji rade puno radno vrijeme u poduzećima s $10 \mathrm{i}$ više zaposlenika, a stariji su od 21 godine prima manje od $105 \%$ minimalne plaće. Kao sastavni dio ovog rada pripremljena je i procjena proporcije zaposlenika s plaćom manjom od 105\% minimalne plaće na temelju Ankete o radnoj snazi ili Ankete o dohotku stanovništva, koja za razliku od gore navedenih procjena uzima u obzir zaposlenike i kod pravnih i kod fizičkih osoba, ali se i dalje fokusira na radnike $u$ punom radnom vremenu. Podaci iz Ankete o radnoj snazi pokazuju kako je udio radnika obuhvaćenih minimalnom plaćom postupno rastao, od ispod 4\% 2007. na preko $10 \%$ 2014. godine. Podaci na temelju Ankete o dohotku stanovništva u 2014. ukazuju na niži postotak u 2014. godini, 5\%. Raspon razlika u procjenama temeljenih na različitim izvorima je relativno velik, a uzroci tih razlika navedeni su kod prikaza rezultata analize anketnih podataka u drugom dijelu rada.

U usporedbi s drugim zemljama EU-a iznos minimalne plaće u Hrvatskoj je među nižima, ali približno u skladu s razinom razvijenosti ili čak i nešto iznad toga ako se BDP po stanovniku uzme kao mjera razvijenosti. ${ }^{2}$ Hrvatska je početkom 2018.

\footnotetext{
${ }^{2}$ Uz koeficijente iz jednostavne regresijske ocjene po zemljama EU-a uz minimalne plaće kao zavisnu varijablu i BDP po stanovniku kao nezavisnu varijablu proizlazi da bi za razinu BDP-a koji ima Hrvatska minimalna plaća bila niža od razine propisane u Hrvatskoj.
} 
imala šestu najnižu minimalnu plaću u EU u iznosu od 462 eura. Nižu minimalnu plaću imale se Bugarska, Litva, Rumunjska, Latvija i Mađarska, a tek nešto višu imale su Češka, Slovačka, Estonija i Poljska. Najvišu minimalnu plaću u EU propisao je Luksemburg, gdje ona iznosi 1999 eura. U pogledu udjela minimalne u prosječnoj plaći, podaci Eurostata za 2016. godinu pokazuju da je Hrvatska sa 40,2\% imala peti najmanji udio u EU. Manji udio imale su Španjolska, Češka, Estonija i Slovačka, a najviši udio imala je Slovenija s 50,7\%. ${ }^{3}$

\section{PROFIL PRIMATELJA MINIMALNE PLAĆE}

Pregled karakteristika zaposlenika koji primaju minimalnu plaću prikazan u ovome poglavlju temelji se na individualnim podacima iz Ankete o radnoj snazi (ARS). Analizirani su kvartalni podaci koji su zbrojeni na godišnjoj razini za 2007., 2009., 2012. i 2014. godinu. ${ }^{4}$ Anketu provodi Državni zavod za statistiku u skladu s metodološkim preporukama Eurostata, što bi trebalo jamčiti reprezentativnost uzroka koji je odabran kao slučajni dvoetapni stratificirani uzorak ${ }^{5}$. U anketiranim kućanstvima po obuhvaćenim godinama bilo je ukupno 45318 osoba 2007. godine, 42295 osoba 2009. godine, 37302 osoba 2012. godine $i$ 38206 osoba 2014. godine.
Za svrhe ovoga istraživanja, promatrani su zaposlenici, tj. osobe koje na ime i račun poslodavca obavljaju nesamostalni rad. $\mathrm{U}$ analizu nisu uključeni poljoprivrednici, obrtnici i samostalne profesije zbog nestabilnosti njihovih primanja, a koja najčešće nemaju samo karakter plaće, već osim naknade za rad uključuju i naknadu za poduzetničke aktivnosti. U literaturi se za navedenu grupu radnika često koristi i izraz "zavisni radnici« (eng. dependent workers). Obuhvaćeni su samo oni zaposlenici koji rade između 36 i 40 sati tjedno (puno radno vrijeme) i koji su odgovorili na pitanje o visini neto plaće.

S obzirom na uočeno zaokruživanje odgovora na pitanje o visini neto plaće, definicija zaposlenika koji prima minimalnu plaću prilagođena je na način da uključuje zaposlenike koji su primali do $105 \%$ minimalne plaće za promatranu godinu. Podaci iz Ankete odnose se na uobičajenu mjesečnu neto plaću. Kako se u Hrvatskoj minimalna plaća određuje u bruto iznosu, trebalo je uskladiti anketni podatak o neto plaći sa zakonski određenom minimalnom plaćom u bruto iznosu. Iznos minimalne plaće u neto iznosu procijenjen je na način da se od bruto iznosa izdvojio doprinos za mirovinsko osiguranje ( $20 \%$ bruto iznosa), te se izračunala porezna obveza uz pretpostavljeni osobni odbitak uz faktor 1 (visina odbitka za osobu bez uzdržavanih članova kućanstva sukladno Zakonu o porezu na do-

\footnotetext{
${ }^{3}$ Baza podataka Eurostata earn_mw_avgr2 (pristupljeno 4. ožujka 2018.).

${ }^{4}$ Izabrane su one godine za koje se vjeruje da dobro ilustriraju stanje u ključnim točkama u razvoju minimalne plaće u Hrvatskoj. Početna, 2007., godina pokriva pretkrizno razdoblje i godina je prije prvog značajnijeg povećanja minimalne plaće. 2009. godina izabrana je kao godina u kojoj su uključeni svi učinci povećanja iz 2008. godine. Naime, anketa za 2008. odražava mješavinu podataka prije i nakon povećanja minimalne plaće iz lipnja 2008. i zato ne bi dala najbolju sliku stanja. Slično tome, izabrane su 2012. i 2014. godine, pri čemu 2012. godina odražava stanje prije novog povećanja minimalne plaće iz sredine 2013., a u 2014. se očekuje da će se prepoznati učinci povećanja na broj i strukturu primatelja minimalne plaće. Izbor određenih godina umjesto kontinuiranog praćenje vezan je uz racioniranje troškova, kako vremena obrade tako i troškova kupovine baza podataka. Nadalje, zbog strožih pravila DZS-a o zaštiti privatnosti, mikro podaci iz ARS-a o plaćama za godine nakon 2014. su grupirani i stoga ne mogu više poslužiti kao pouzdana osnova za procjenu broja i profila primatelja minimalne plaće u Hrvatskoj.

${ }^{5}$ Više o metodologiji i uzorkovanju Ankete o radnoj snazi vidjeti na primjer u Državni zavod za statistiku (2013., 2017.: 136-142).
} 
hodak u promatranom razdoblju), uz važeće porezne stope, te pretpostavljenu stopu prireza od $10 \%$, a što približno odgovara prosječnoj stopi prireza koju plaćaju zaposlenici u Hrvatskoj. Kroz godine događale su se određene promjene u poreznome zakonodavstvu (izmjene poreznih stopa, poreznih razreda, osobnog odbitka) kao i u zakonodavstvu minimalne plaće. Za svaku je godinu kao primatelj minimalne plaće identificirana osoba koja je primala neto plaću ispod granice od $105 \%$ procijenjene minimalne plaće u neto iznosu, sukladno gore navedenim kriterijima. Osnovni podaci o procjeni granice minimalne plaće prikazani su u Tablici 1.

Tablica 1.

Bruto minimalna plaća i procjena neto minimalne plaće od 2007. do 2014.

\begin{tabular}{cccccc}
\hline Godina & Razdoblje primjene* & $\begin{array}{c}\text { Bruto MP } \\
(\mathrm{kn})\end{array}$ & $\begin{array}{c}\text { Procjena } \\
\text { neto } \\
\text { iznosa } \\
\mathrm{MP}(\mathrm{kn})\end{array}$ & $\begin{array}{c}\text { Procije- } \\
\text { njena za- } \\
\text { okružena } \\
\text { granica } \\
\text { od 105\% } \\
\mathrm{MP}(\mathrm{kn})\end{array}$ & $\begin{array}{c}\text { Unutargodišnje pro- } \\
\text { majene koje su utjecale }\end{array}$ \\
\hline 2007. & od 1.1. do 31.12. 2007. & 2298,00 & 1799,06 & 1890,00 & ne plaće \\
\hline 2009. & od 1.1. do 31.5.2009. & 2747,00 & 2132,00 & 2240,00 & \\
\cline { 2 - 6 } & od 1.6.2009. do 31.12.2009. & 2814,00 & 2176,75 & 2290,00 & $\begin{array}{c}\text { rast minimalne plaće } \\
\text { od 1. lipnja 2009. }\end{array}$ \\
\hline 2012. & od 1.1.2012. do 28.2.2012. & 2814,00 & 2191,64 & 2300,00 & $\begin{array}{c}\text { promjena poreznih } \\
\text { stopa (NN, 80/2010.) }\end{array}$ \\
\cline { 2 - 6 } & od 1.3.2012. do 31.12.2012. & 2814,00 & 2244,44 & 2360,00 & $\begin{array}{c}\text { povećanje osob- } \\
\text { nog odbitka (NN, } \\
\text { 22/2012.) }\end{array}$ \\
\hline 2014. & Od 1.1. do 31.12. 2014. & 3017,61 & 2385,83 & 2505,00 & -
\end{tabular}

Napomene: * U tablici se razdoblje primjene odnosi na primjenu odgovarajućeg neto iznosa minimalne plaće za procjenu je li ispitanik primatelj minimalne plaće ili ne, a u ovisnosti o datumu anketiranja u Ankete o radnoj snazi.

Izvor: Procjene autora.

Vrijedi spomenuti da podaci Ankete o radnoj snazi jedini pružaju usporedivu procjenu kretanja minimalne plaće tijekom dužeg vremenskog razdoblja. Podaci iz ostalih izvora daju procjenu obuhvata u jednome trenutku, ili u kraćem razdoblju. Tako na primjer Anketa o dohotku stanovništva postoji tek od 2010. godine. Anketi o radnoj snazi kao izvoru podataka o isplatama minimalne plaće može se uputiti standardna zamjerka vezana za sve anketne podatke, a tiče se mogućeg podcjenjivanja iznosa plaća u odgovorima ispitanika tijekom anketiranja. No, ako je to podcjenjivanje u relativnome obliku stabilno tijekom vremena, onda prezentirani podaci možda precjenjuju proporciju primatelja minimalne plaće, ali bi oni mogli prilično dobro odražavati smjer kretanja, odnosno dokumentirati trend obuhvata minimalne plaće u Hrvatskoj. Manjkavost Ankete o radnoj snazi je i nedostatak pouzdanih podatka o dohotku kućanstava, točnije niska stopa odgovora na pitanja o dohotku kućanstva. ${ }^{6}$

${ }^{6}$ Na pitanje o ukupnome neto prihodu kućanstva u ARS-u primatelji minimalne plaće često ne daju odgovor, tako da je prosječna stopa odgovara 2007 . bila18,3\%, 2009. godine $22,7 \%, 2012$. godine $18,9 \%$, a 2014. godine $28,7 \%$. 
Zbog toga se za procjenu materijalnog statusa primatelja minimalne plaće $\mathrm{u}$ drugom dijelu ovog rada razmatraju podaci temeljem Ankete od dohotku stanovništva.

Rezultati obrade anketnih podataka pokazuju postupni rast udjela zaposlenika koji primaju minimalnu plaću ili plaću nižu od minimalne (Tablica 2.). Dok je 2007. procijenjeni udio zaposlenika s minimalnom plaćom u ukupnoj zaposlenosti u punom radnom vremenu iznosio 3,2\%, u 2009. (nakon donošenja prvog Zakona o minimalnoj plaći) on je porastao na $7,3 \%$. Recesija je donijela daljnji rast na 9,4\% u 2012., a nakon donošenja novog Zakona o minimalnoj plaći taj je udio povećan na $10,3 \%$ u 2014. Kod privatnih poslodavaca je udio zaposlenika na minimalnoj plaći dosegao preko $10 \%$ već u 2009 . Veći udio u privatnom sektoru je očekivan s obzirom da država kao poslodavac, posebice u javnim djelatnostima (javna administracija, obrazovanje, zdravstvo, kultura) u većoj mjeri zapošljava radnike s višim obrazovanjem i shodno tome višim plaćama, pa je zato obuhvat minimalnom plaćom manji.

Ovdje treba ukazati na nepreciznost procjena obuhvata minimalne plaće baziranih na anketnim podataka. Osim standardnog opreza kod korištenja anketa i podataka baziranih na uzorku, u ovom se slučaju radi o učincima zaokruživanja odgovara o visini neto plaća. To može značajno utjecati na precizno identificiranje radnika koji primaju minimalnu plaću. Upravo takav je slučaj opažen kod podataka za 2014. godinu gdje procijenjena proporcija primatelja minimalne plaće značajno ovisi o tome smatrala li osoba s neto plaćom od 2500 kuna primateljem minimalne plaće ili ne. Usvojeni kriterij od $105 \%$ procijenjene minimalne plaće u neto iznosu (2 505 kuna) govori da bi se primatelje takve plaće trebalo obuhvatiti u analizi primatelja minimalne plaće. U tom slučaju je procijenjeni udio primatelja minimalne plaće $10,3 \%$. No, kako je sama minimalne plaća u neto iznosu procijenjena na 2385,83 kuna, a uz proširenje obuhvata minimalne plaće na sve s neto plaćom do 2 500 kuna (104,7\% minimalne plaće), ali ne uključujući taj iznos, dobiva se proporcija primatelja minimalne plaće od $6,7 \%$. Tako se procijenjena proporcija primatelja minimalne u 2014. zapravo kreće od 6,7 \% do $10,3 \%$ ovisno o time jesu li uključeni radnici s plaćom od 2500 kuna ili ne. Slično, samo u manjem obujmu, događa se s granicom od 2300 kuna u 2012. godini. Stoga rezultate iz Tablice 2. ne treba gledati kao precizne izračune već kao procjene udjela radnika čija je plaća bila značajno pod utjecajem politike minimalne plaće.

Tablica 2.

Radnici obuhvaćeni minimalnom plaćom od 2007. do 2014. godine (u \% ukupne zaposlenosti)

\begin{tabular}{|c|c|c|c|c|}
\hline & 2007. & 2009. & 2012. & 2014. \\
\hline \multicolumn{5}{|l|}{ Svi poslodavci } \\
\hline $\begin{array}{l}\text { Udio zaposlenika koji primaju do } 105 \% \text { mi- } \\
\text { nimalne plaće }\end{array}$ & 3,2 & 7,3 & 9,4 & 10,3 \\
\hline \multicolumn{5}{|l|}{ Privatni poslodavci } \\
\hline $\begin{array}{l}\text { Udio zaposlenika koji primaju do } 105 \% \text { mi- } \\
\text { nimalne plaće }\end{array}$ & 5,1 & 11,6 & 14,2 & 14,2 \\
\hline
\end{tabular}

Izvor: Procjena autora na osnovi mikro podataka iz Ankete o radnoj snazi. 
Uvid u cijelu distribuciju plaća i promjenu koja se dogodila između 2007. i 2014. na temelju grupiranih podataka o visini neto plaće može se dobiti iz ilustracije na Slici 2. Opaža se pomak procijenjene krivulje distribucije plaća udesno kao rezultat rasta plaća tijekom vremena. Procjena nejednakosti u raspodjeli plaća korištenjem Ginijevog koeficijenta pokazuje vrijednosti od 0,224 u 2007. i 0,220 u 2014. godini, te ukazuje da nije došlo do značajnije promjene $\mathrm{u}$ promatranom razdoblju. ${ }^{7}$

Slika 2.

Distribucija neto plaća u 2007. i 2014.

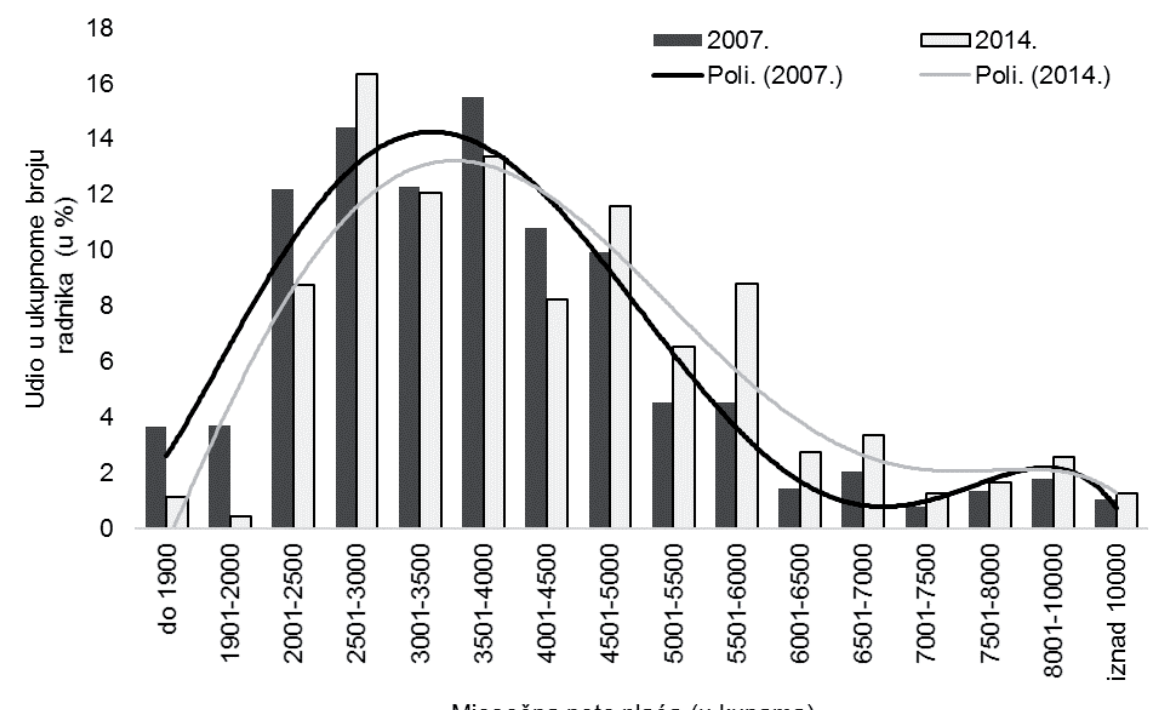

Izvor: Procjena autora na osnovi mikro podataka iz Ankete o radnoj snazi.

Najznačajnije karakteristike zaposlenika koji primaju minimalnu plaću, točnije primaju plaću do $5 \%$ veću od minimalne plaće, prikazane su u Tablici 3. Uspoređene su dvije najudaljenije godine, 2007. i 2014., kako bi se što jasnije uočile promjene koje su u međuvremenu nastale. Na promjenu strukture utjecalo je opaženo širenje obuhvata minimalne plaće zbog rasta mini- malne plaće bržeg od rasta prosječne plaće čime se zahvaćaju nove skupine zaposlenika drugačije strukture od ranijih primatelja minimalne plaće. No, na nju su utjecala još dva značajna faktora, jedan je gospodarska kriza i promjena sektorske strukture gospodarstva i uz to povezana promjena kvalifikacijske strukture radne snage, a drugi je mjera stručnog osposobljavanja za rada bez zasnivanja radnog odnosa (SOR).

${ }^{7}$ Problem zaokruživanja podataka o plaćama utjecat će i na mjere nejednakosti u raspodjeli plaća, no ne u tolikoj mjeri da bi značajno promijenio trend, jer u obje promatrane godine postoje vrijednosti oko kojih se grupiraju iznosi neto plaća navedeni od ispitanika $u$ anketama. 
Učinci navedenih faktora mogu se prepoznati u pojedinim elementima promjene strukture primatelja minimalne plaće, premda ih nije moguće precizno izolirati. Ipak, kako bi se dobio uvid u utjecaj prvog spomenutog faktora, zahvaćanje šire skupine zaposlenika zbog rasta minimalne plaće bržeg od rasta prosječnih plaća na donjem kraju distribucije, u Tablici 3. je prikazana struktura zaposlenika koji su 2007. godine imali plaću veću od minimalne, ali manju od minimalne plaće iz 2014. kao aproksimaciju strukture novozahvaćenih radnika. Konkretno, radi se o skupini čija se plaća u 2007. godini kretala između 1890 kuna (105\% minimalne plaće iz 2007.) i 2505 kuna (105\% minimalne plaće iz 2014.). Temeljem strukture te skupine može se u grubo procijeniti u kojoj bi mjeri promjena strukture primatelja minimalne plaće između 2007. i 2014. mogla biti uvjetovana samim rastom minimalne plaće i zahvaćanjem novih kategorija zaposlenika.

U skupini zaposlenika koji primaju minimalnu plaću ima osjetno više žena nego muškaraca (Tablica 3.). No, udio žena je smanjen između 2007., kada su one činile tri četvrtine primatelja, i 2014., kada su činile manje od dvije trećine primatelja. Slika 3. pokazuje da je pad udjela žena postupni proces nakon 2007. godine. On je jednim dijelom uvjetovan rastom minimalne plaće i zahvaćanjem šire skupine zaposlenika u kojoj je sada nešto niža proporcija žena nego kod primatelja minimalne plaće u 2007., kao što to pokazuje usporedba drugog i trećeg stupca iz Tablice 3. Isto tako, pad udjela mogao bi se objasniti smanje- njem zaposlenosti u industrijama u kojima je postojala velika proporcija primatelja minimalne plaće i visok udio žena, a to su prije svega tekstilna i obućarska industrija. Nažalost, ARS ne omogućava preciznu i detaljnu usporedbu po sektorima kako zbog veličine uzroka tako i zbog promjene klasifikacije djelatnosti koja se dogodila 2009. godine, ali na takvo objašnjenje upućuju nalazi iz Nestić i sur. (2018.).

Primatelji minimalne plaće najčešće su osobe s nižim obrazovanjem, premda je njihov udio 2014. značajno smanjen u odnosu na 2007. Tako je udio osoba sa završenom osnovnim školom 2007. iznosio 31\%, da bi 2014. on pao na $19 \%$. S druge strane, udio osoba s višim i visokim obrazovanje povećan je s 5\% u 2007. na preko $9 \%$ u 2014. Takva se kretanja ne mogu objasniti zahvaćanjem bitno drugačije strukture zaposlenika tijekom relativnog rasta minimalne plaće (treći stupac Tablice 3.), ali bi se mogla objasniti i aktivnom politikom zapošljavanja, prije svega u okviru programa stručnog osposobljavanja za rad bez zasnivanja radnog odnosa (SOR) i programa potpora za zapošljavanje. ${ }^{8}$ Naime, te su mjere dovele na tržište rada veći broj mlađih i obrazovanijih osoba, ali uz niže plaće. U slučaju SOR-a bila je isplaćivana naknada koja je niža od minimalne plaće. Iako naknadu isplaćuje zavod za zapošljavanje i tehnički to nije plaća, pa niti ne podliježe regulativi minimalne plaće, ispitanici u anketi zasigurno nisu vodili računa o tehničkim detaljima. ${ }^{9}$

\footnotetext{
8 O obuhvatu i postupnoj ekspanziji tih mjera, koji nakon 2012. počinju značajno utjecata na kretanja na hrvatskom tržištu rada u Hrvatskoj, vidjeti u HZZ (2016.).

${ }^{9}$ Nažalost, u samoj Anketi o radnoj snazi nije moguće nedvosmisleno identificirati korisnike SOR-a, tako da nije niti moguća procizna procjena učinka ove mjere na broj i strukturu primatelja minimalne plaće.
} 
Tablica 3.

Karakteristike primatelja minimalne plaće, 2007. i 2014. godina

\begin{tabular}{|c|c|c|c|c|c|}
\hline & 2007. & & & 2014. & \\
\hline Karakteristike & $\begin{array}{c}\text { Zaposlenici } \\
\text { koji primaju } \\
\text { do } 105 \% \\
\text { minimalne } \\
\text { plaće iz } \\
2007 .\end{array}$ & $\begin{array}{c}\text { Zaposle- } \\
\text { nici koji } \\
\text { primaju } \\
\text { između } \\
105 \% \\
\text { min. plaće } \\
\text { iz } 2007 . \text { i } \\
2014 . \\
\end{array}$ & $\begin{array}{l}\text { Svi zapo- } \\
\text { slenici }\end{array}$ & $\begin{array}{c}\text { Zaposle- } \\
\text { nici koji } \\
\text { primaju } \\
\text { do } 105 \% \\
\text { minimalne } \\
\text { plaće iz } \\
2014 .\end{array}$ & $\begin{array}{l}\text { Svi za- } \\
\text { poslenici }\end{array}$ \\
\hline $\begin{array}{l}\text { Udio onih koji žive u seoskom } \\
\text { naselju ili kući izvan naselja (\%) }\end{array}$ & 58,9 & 51,4 & 39,7 & 64,7 & 48,9 \\
\hline Udio nositelja kućanstva (\%) & 18,3 & 23,5 & 39,5 & 28,7 & 42,9 \\
\hline Udio žena (\%) & 75,9 & 63,3 & 48,2 & 63,3 & 48,6 \\
\hline $\begin{array}{l}\text { Udio radnika rođenih u Hrvatskoj } \\
(\%)\end{array}$ & 81,3 & 87,9 & 89,6 & 90,5 & 89,2 \\
\hline $\begin{array}{l}\text { Udio oženjenih/udanih radnika/ca } \\
(\%)\end{array}$ & 71,8 & 63,2 & 68,6 & 58,4 & 68,0 \\
\hline $\begin{array}{l}\text { Udio radnika sa završenom } \\
\text { osnovnom školom (\%) }\end{array}$ & 31,1 & 26,3 & 11,2 & 18,9 & 8,6 \\
\hline $\begin{array}{l}\text { Udio visokoobrazovanih radnika } \\
(\%)^{*}\end{array}$ & 5,4 & 1,0 & 22,6 & 9,4 & 28,0 \\
\hline $\begin{array}{l}\text { Udio radnika zaposlenih na } \\
\text { neodređeno }(\%)\end{array}$ & 75,5 & 79,2 & 88,9 & 63,8 & 85,7 \\
\hline $\begin{array}{l}\text { Udio radnika koji su na prethodnome } \\
\text { poslu radili kao zavisni radnici (\%) }\end{array}$ & 33,2 & 45,6 & 50,7 & 38,8 & 49,7 \\
\hline Prosječan broj godina radnoga staža & 14,7 & 14,6 & 18,4 & 13,6 & 18,7 \\
\hline $\begin{array}{l}\text { Udio radnika koji obavlja dodatni } \\
\text { podao }(\%)\end{array}$ & 2,9 & 3,8 & 3,9 & 1,7 & 2,7 \\
\hline $\begin{array}{l}\text { Udio radnika koji ne žele mijenjati } \\
\text { glavni posao ili naći dodatni posao } \\
(\%)\end{array}$ & 75,9 & 84,2 & 91,6 & 82,8 & 91,9 \\
\hline $\begin{array}{l}\text { Udio radnika koji su prijavljeni kao } \\
\text { nezaposleni na HZZ-u (\%) }\end{array}$ & 1,7 & 0,6 & 0,4 & 0,7 & 0,5 \\
\hline $\begin{array}{l}\text { Udio radnika koji su financijsku } \\
\text { situaciju kućanstva ocijenili lošom i } \\
\text { uglavnom lošom }(\%)^{* \star}\end{array}$ & 72,7 & 71,3 & 42,3 & 71,0 & 48,3 \\
\hline Udio mladih do 24 godine (\%) & 11,2 & 16,3 & 8,7 & 13,2 & 5,6 \\
\hline Udio mladih do 29 godina (\%) & 22,0 & 30,6 & 19,6 & 29,0 & 16,1 \\
\hline
\end{tabular}

Izvor: Procjena autora na osnovi mikro podataka iz Ankete o radnoj snazi.

Napomene: * Visokoobrazovani radnici u 2007. godini obuhvaćaju radnike koji su završili višu školu, 1. stupanj fakulteta, stručni studij, fakultet, umjetničku akademiju, sveučilišni studij, magistarski ili doktorski studij. Visokoobrazovani u 2014. godini obuhvaćaju radnike koji su završili kratki stručni studij (u trajanju 2-2,5 godine), preddiplomski stručni studij i preddiplomski sveučilišni studij, diplomski sveučilišni studij, integrirani preddiplomski i diplomski sveučilišni studij, specijalistički diplomski i stručni studij i poslijediplomski specijalistički studij, magisterij znanosti i specijalistički magistarski, doktorski studij.

** U 2007. godini na pitanje o financijskoj situaciji kućanstva odgovorilo je 18,3\% radnika - primatelja minimalne plaće dok je 39,4 \% zavisnih radnika odgovorilo na ovo pitanje; u 2014. godini na pitanje o financijskoj situaciji kućanstva odgovorilo je 28,7 \% radnika - primatelj minimalne plaće dok je 41,8 \% zavisnih radnika odgovorilo na ovo pitanje. 
Aktivne mjere zapošljavanja tako su vjerojatno utjecale i na strukturu zaposlenika s niskim plaćama (do 105\% minimalne plaće), što se osim u porastu udjela visokoobrazovanih osoba, vidi i u porastu udjela mlađih osoba. Tako je među primateljima minimalne plaće u 2014. bilo gotovo 30\% mladih do 29 godina starosti, što je veći udio nego 2007., a zbog čega je značajno smanjen i udio oženjenih/udanih radnika/ radnica, koji je 2014. pao na ispod $60 \%$. No, pomak strukture primatelja minimalne plaće prema mlađim dobnim skupinama dijelom je i rezultat proširenja obuhvata minimalne plaće zbog njezinog rasta i zahvaćanja novog kruga primatelja s nešto višim plaćama u čijoj strukturi ima više mladih.

Slika 3.

Spolna struktura zaposlenika koji primaju minimalnu plaću od 2007. do 2014. godine

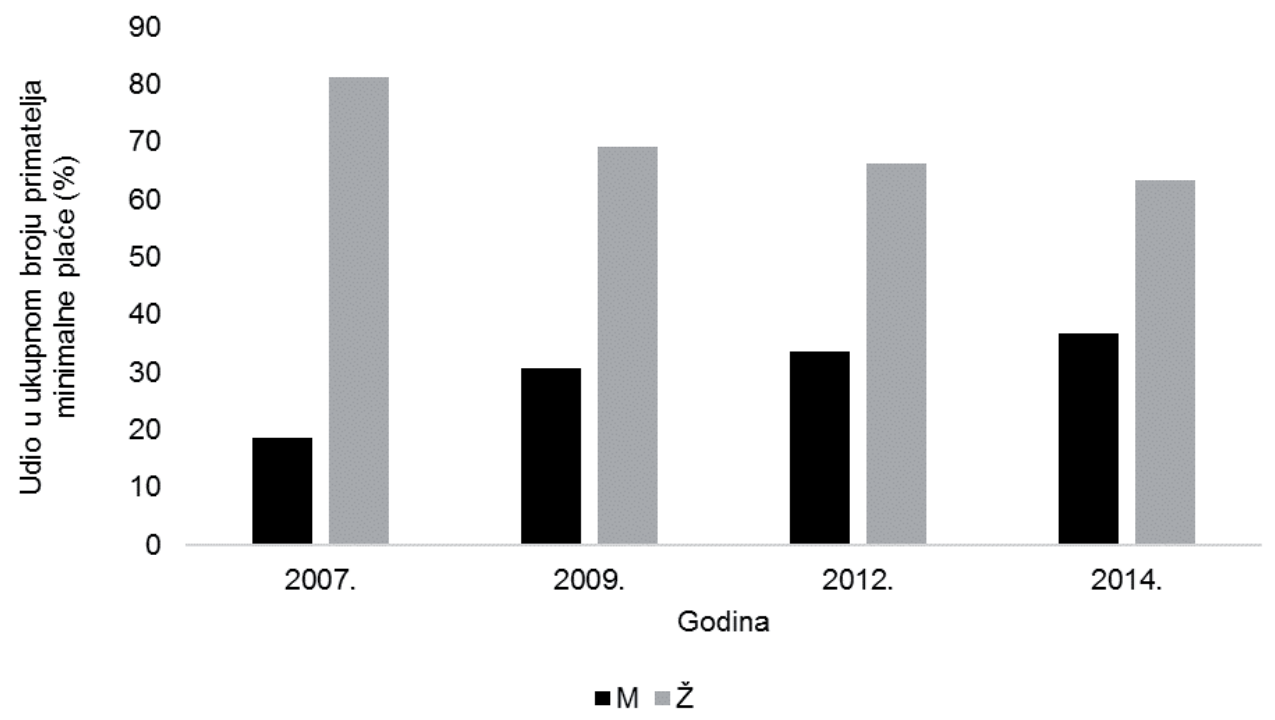

Izvor: Procjena autora na osnovi mikro podataka iz Ankete o radnoj snazi. 
Slika 4.

Starosna struktura primatelja minimalne plaće, 2007. i 2014. godina

2007.

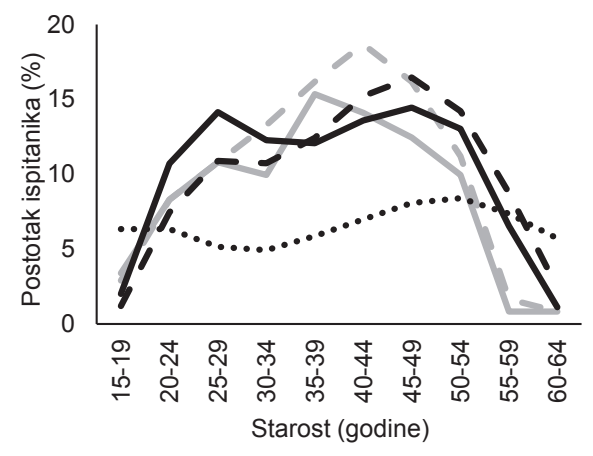

Primatelji minimalne plaće u privatnom sektoru

- Primatelji minimalne plaće u svim sektorima

- Zavisni radnici u svim sektorima

Zavisni radnici u privatnom sektoru

...... ARS uzorak
2014.

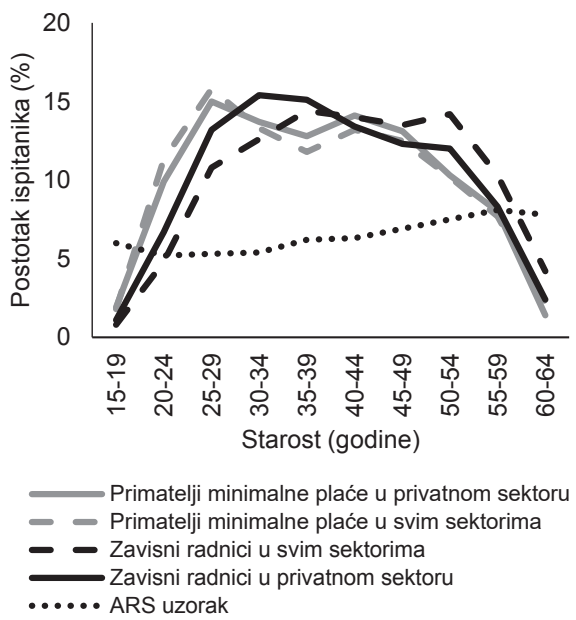

Izvor: Procjena autora na osnovi mikro podataka iz Ankete o radnoj snazi.

Pomak strukture po dobnim skupinama pokazuje i Slika 4. U 2014., u usporedbi s 2007., povećan je udio primatelja minimalne plaće u dobi 20-29 godina, a smanjen udio radnika u dobi od 35 do 45 godina. Usporedba dobne strukture primatelja minimalne plaće sa strukturom ukupno zaposlenih ukazuje da je u 2014. godini bilo iznadproporcionalno više mlađih primatelja minimalne plaće, što nadalje upućuje da su mladi imali iznadprosječnu vjerojatnost za rad na minimalnoj plaći u odnosu na ostale dobne skupine. U 2007. to nije bio slučaj već je tada rizik primanja minimalne plaće bio povećan za radnike u dobi od 30 do 45 godina.

Smanjenje udjela radnika s ugovorom na neodređeno vrijeme među primateljima minimalne plaće isto bi tako mogao biti rezultat aktivne politike zapošljavanja, ali i dugoročnijeg trenda gdje se najveći dio novog zapošljavanja obavlja putem ugovora na određeno vrijeme, a upravo novo zapošljavanje ima veću šansu da bude plaćeno minimalnom plaćom. Preko $70 \%$ primatelja minimalne plaće financijsku situaciju kućanstva ocjenjuju lošom i uglavnom lošom, kako 2007., tako i 2014. No, kod primatelja minimalne plaće opažen je relativno visok postotak onih koji ne žele mijenjati glavni posao ili naći dodatni posao, i to više 2014. (83\%) nego 2007 . godine $(76 \%)$, što može ukazivati na slabe perspektive nalaženja drugog posla, a što je bilo više izraženo u još uvijek kriznoj 2014., nego u pretkriznoj 2007. godini. Začuđujuće je visok postotak onih koji preferiraju status quo u zaposlenju kod ukupno zaposlenih bez obzira na plaću (93\% u 2014.), što je još jedan pokazatelj slabe dinamike hrvatskog gospodarstva. Od ostalih karakteristika primatelja minimalne plaće, u usporedbi s ukupno zaposlenima, oni češće žive u ruralnim sredinama, rjeđe su nositelji kućanstva (premda ih je više 2014. nego 2007.), imaju kraći radni staž i rjeđe rade na dodatnom poslu.

S obzirom na značajke života u kućanstvima, najveći broj primatelja minimalne 
plaće živi u kućanstvu s dvije osobe $(37 \%$ u 2014.), nakon čega slijede kućanstva s jednom osobom $(29 \%)$ te kućanstva s tri osobe (20\%). Na trenutnom zaposlenju primatelji minimalne plaće počeli su raditi javljanjem na natječaj za posao (31\%), kontaktiranjem osobno s poslodavcem (25\%) ili raspitivanjem izravno kod poslodavca (16\%). Prije trenutnoga zaposlenja, njih gotovo $46 \%$ je bilo nezaposleno i prijavljeno na HZZ-u, a $32 \%$ radilo je u privatnome sektoru.

Analiza distribucije primatelja minimalne plaće po djelatnostima i spolu za 2014.

Tablica 4.

Struktura zaposlenika primatelja minimalne plaće po spolu i po djelatnostima (odjeljci) (u \% ukupne zaposlenosti primatelja minimalne plaće), 2014. godina

\begin{tabular}{|c|c|c|}
\hline \multirow{2}{*}{ Djelatnost } & \multicolumn{2}{|c|}{2014.} \\
\hline & MUŠKARCI & ŽENE \\
\hline Poljoprivreda, šumarstvo i ribarstvo & 2,0 & 1,7 \\
\hline Rudarstvo i vađenje & - & - \\
\hline Prerađivačka industrija & 13,6 & 19,4 \\
\hline $\begin{array}{l}\text { Opskrba vodom; uklanjanje otpadnih voda, gospodarenje otpadom te } \\
\text { djelatnosti sanacije okoliša }\end{array}$ & 0,7 & - \\
\hline Građevinarstvo & 6,0 & 0,3 \\
\hline Trgovina na veliko i na malo; popravak motornih vozila i motocikala & 3,3 & 13,6 \\
\hline Prijevoz i skladištenje & 2,0 & 0,9 \\
\hline Djelatnosti pružanja smještaja te pripreme i usluživanja hrane & 1,3 & 6,7 \\
\hline Informacije i komunikacije & - & 0,4 \\
\hline Financijske djelatnosti i djelatnosti osiguranja & - & 0,6 \\
\hline Poslovanje nekretninama & - & 0,1 \\
\hline Stručne, znanstvene i tehničke djelatnosti & 0,3 & 1,1 \\
\hline Administrativne i pomoćne uslužne djelatnosti & 2,6 & 3,3 \\
\hline Javna uprava i obrana; obvezno socijalno osiguranje & 0,9 & 3,7 \\
\hline Obrazovanje & 0,9 & 3,4 \\
\hline Djelatnosti zdravstvene zaštite i socijalne skrbi & 1,4 & 3,2 \\
\hline Umjetnost, zabava i rekreacija & 0,6 & 0,7 \\
\hline Ostale uslužne djelatnosti & 1,1 & 3,3 \\
\hline $\begin{array}{l}\text { Djelatnosti kućanstava kao poslodavaca; djelatnosti kućanstava koja } \\
\text { proizvode različitu robu i obavljaju različite usluge za vlastite potrebe }\end{array}$ & - & 0,6 \\
\hline Djelatnosti izvanteritorijalnih organizacija i tijela & - & 0,1 \\
\hline
\end{tabular}

Izvor: Procjena autora na osnovi mikro podataka iz Ankete o radnoj snazi.

\footnotetext{
${ }^{10}$ Od 2009. godine u Hrvatskoj je u upotrebi nova Nacionalna klasifikacije djelatnosti, zbog čega nije bilo moguće napraviti usporedbu sa sektorskom strukturom primatelja minimalne plaće s 2007.
}

godinu ukazuje na segregaciju primatelja minimalne plaće po spolu u određenim djelatnostima (Tablica 4.) ${ }^{10}$. Najveći broj pria slijede trgovina na veliko i malo (17\%) i djelatnost pružanja smještaja te pripreme i usluživanja hrane (8\%). Muškarci kao primatelji minimalne plaće su u najvećoj mjeri u 2014. godini obavljali poslove u prerađivačkoj industriji i građevinarstvu dok su žene koje primaju minimalnu plaću bile mahom zaposlene u prerađivačkoj industriji i djelatnosti trgovine na veliko i malo. matelja minimalne plaće, neovisno o spolu, zaposlen je u prerađivačkoj industriji (33\%), 


\section{MATERIJALNO STANJE KUĆANSTAVA U KOJIMA ŽIVE PRIMATELJI MINIMALNE PLAĆE}

Informacije o materijalnom stanju kućanstava primatelja minimalne plaće mogu dati dobar uvid u rizik siromaštva s kojim su ona suočena, kao i u potencijalnu učinkovitost politike minimalne plaće u borbi protiv siromaštva. Anketa o radnoj snazi ne daje dovoljno informacija o dohotku kućanstava prije svega zbog visoke stope neodgovora na pitanje o ukupnom dohotku kućanstva. S druge strane, Anketa o dohotku stanovništva (ADS) je posebno dizajnirana upravo da prikupi podatke o dohocima kućanstava, postoji velik broj pitanja o različitim oblicima dohotka, ali i dovoljno informacija o radnom statusu članova kućanstava zbog čega je ona prikladna za razmatranje materijalnog položaja primatelja minimalne plaće.

ADS je anketa koja je u hrvatski statistički sustav uvedena 2010. godine. Radi se o lokalnoj varijanti standardizirane europske Ankete o dohotku i životnom standard (SILC - Survey on Income and Living Conditions) koju provodi Državni zavod za statistiku u metodološkoj suradnji s Eurostatom. Za potrebe ovog istraživanja razmotrene su ankete provedene 2013., 2014. i 2015. godine korištenjem anonimiziranih individualnih podataka. S obzirom da se prikupljeni anketni podaci o dohotku odnose na prethodnu kalendarsku godinu, to znači da te informacije treba pripisati godinama 2012., 2013. i 2014. Tako je ovom prilikom i učinjeno zato da bi se ti podaci ispravno povezali s razinom minimalne plaće za određenu godinu. Rezultati temeljem ADS-a tada se mogu usporediti s rezultatima iz ARS-a koje smo prethodno predstavili.

Primatelji minimalne plaće u ADS-u identificirani su kao zaposlenici s punim radnim vremenom i bruto plaćom manjom od 105\% iznosa minimalne place. Moguće podcjenjivanje iznosa plaća koje je uobičajeno u anketnim istraživanjima u slučaju ADS-a vjerojatno nije značajnije izraženo, odnosno ne bi trebalo značajnije utjecati na rezultate o primateljima minimalne plaće. Naime, prosječna bruto plaća za 2014. prema podacima iz ADS-a bila je oko 7000 kuna, dok je službeni podatak DZS-a na temelju ankete poslodavaca iznosio blizu 8 000. Iz tog razumnog raspona odstupanja i očekivanog većeg anketnog podcjenjivanja plaća na gornjem kraju distribucije, odnosno kod najviših plaća, zaključujemo da bi podaci o donjem kraju distribucije plaća gdje pripadaju i primatelji minimalne plaće mogli biti blizu stvarnim isplatama. Razmatranje minimalne plaće ograničeno je na zaposlenike, što znači da nisu uzeti u obzir vlasnici obrta i samostalni djelatnici. Promatraju se samo zaposlenici s punim radnom vremenu, što ne bi trebalo biti ograničavajuće s obzirom da anketa pokazuje da je $98 \%$ zaposlenika zaposleno na puno radno vrijeme, a $2 \%$ na nepuno radno vrijeme.

Zaposlenici na minimalnoj plaći imaju znatno veći rizik siromaštva od ostalih zaposlenika, ali taj je rizik još uvijek manji od prosječnog rizika siromaštva za sve građane Hrvatske. Tablica 5. tako pokazuje da je 2014. godine oko 17\% primatelja minimalne plaće živjelo u siromašnim kućanstvima. Od zaposlenika s plaćom većom od minimalne, njih nešto manje od $4 \%$ živjelo je u kućanstvima izloženima riziku siromaštva. Zaposlene osobe imaju znatno manji rizik siromaštva (ispod 5\%) od rizika za cijelu populaciju (oko 20\%).

Raširenost isplata minimalne plaće $u$ gospodarstvu nije velika, pa je stoga udio primatelja minimalne plaće u stanovništvu kao i među siromašnima relativno mali. Tako ADS pokazuje da je 2014. godine 5\% zaposlenika primalo minimalnu plaću, toč- 
nije plaću manju od $105 \%$ minimalne plaće. To je osjetno manje nego što pokazuju naše prethodne procjene na osnovi Ankete o radnoj snazi. Uz to, usporedba proporcije primatelja minimalne plaće u 2012. i 2014. ukazuje na blago smanjenje u ADS-u, dok su podaci iz ARS-a prikazani u Tablici 2. ukazivali na blagi porast. Opažene razlike kod rezultata na temelju ovih dviju anketa mogu se objasniti relativno velikom gustoćom plaća oko minimalne plaće, posebice oko zaokruženih iznosa plaća (2 500 kuna) pri čemu onda male promjene u odgovorima na pitanje o visini plaće mogu osjetno utjecati na promatrane pokazatelje. Kada se granica za primatelje minimalne plaće $u$ ADS-u pomakne na $110 \%$ zakonske minimalne plaće, tada u 2012. opažamo 7,5\% zaposlenika s minimalnom plaću, te $8 \%$ u 2014. Osim što su ove proporcije bliže opaženima u ARS-u, sada je i trend promijenjen pa ukazuje na blagi porast. S druge strane, ako se u Anketi o radnoj snazi iz 2014. kao primatelji minimalne plaće smatraju samo oni s neto plaćom striktno nižom od 2500 kuna, tada se njihova proporcija smanjuje na $6,7 \%$. To je onda znatno bliže procjeni temeljem ADS-a. Uz to, u ADS-u je procjena napravljena temeljem bruto plaće, a prilikom provođenje same ankete ispitanici se zamole da pripreme i neki dokument o isplati plaće ako ga imaju. U ADS-u postoji i procjena neto plaće. Kada se procjena primatelja minimalne plaće iz ADS-a napravi na temelju neto plaće koja uključuje i neto plaću od 2500 kuna, tada procjena propor-

Tablica 5.

Stope rizika od siromaštva u Hrvatskoj za zaposlenike na minimalnoj plaći

\begin{tabular}{|c|c|c|c|}
\hline & 2012. & 2013. & 2014. \\
\hline Hrvatska ukupno & 19,5 & 19,4 & 20,0 \\
\hline Zaposlenici ukupno & 4,8 & 4,7 & 4,9 \\
\hline Zaposlenici s punim radnim vremenom & 4,7 & 4,7 & 4,7 \\
\hline -zaposlenici na minimalnoj plaći & 18,4 & 16,1 & 17,2 \\
\hline -zaposlenici s plaćom iznad minimalne plaće & 3,5 & 3,9 & 3,9 \\
\hline Nezaposleni & 43,2 & 43,2 & 42,8 \\
\hline \multicolumn{4}{|l|}{ Dodatni pokazatelji } \\
\hline $\begin{array}{l}\text { Udio zaposlenika na minimalnoj plaći među zapo- } \\
\text { slenima u punom radnom vremenu (\%) }\end{array}$ & 6,1 & 5,6 & 5,0 \\
\hline $\begin{array}{l}\text { Udio zaposlenika na minimalnoj plaći u stanovništvu } \\
(\%)\end{array}$ & 1,7 & 1,6 & 1,4 \\
\hline $\begin{array}{l}\text { Udio siromašnih zaposlenika na minimalnoj plaći u } \\
\text { ukupnom broju siromašnih (\%) }\end{array}$ & 1,6 & 1,3 & 1,2 \\
\hline $\begin{array}{l}\text { Udio siromašnih članova kućanstava zaposlenika } \\
\text { na minimalnoj plaći u ukupnom broju siromašnih (\%) }\end{array}$ & 6,9 & 3,9 & 3,9 \\
\hline
\end{tabular}

Napomene: Zaposlenicima na minimalnoj plaći smatraju se osobe s plaćom manjom od 105\% zakonske minimalne plaće. Kao vrijednost minimalne plaća uzeto je stanje u srpnju tekuće godine. Podaci o stopama siromaštva pripisani su godini na koju se odnose podaci o dohotku, a ne na godinu u kojoj su prikupljeni podaci.

Izvor podataka: Izračun autora na osnovi baza individualnih podataka iz ADS-a za 2013., 2014. i 2015. 
cije primatelja minimalne plaće iznosi $9,1 \%$ i blizu je procjeni iz ARS-a. Ove tehničke razlike između anketa i izračuna proporcije primatelja minimalne plaće upućuju nas da kod tumačenja rezultata ne zaboravimo da se radi o procjenama, a stvarne vrijednosti mogu varirati oko procijenjenih. ${ }^{11}$

Ako se usporedba raširenosti isplata minimalne plaće između 2012. i 2014. stavi u kontekst donošenja Zakona o minimalnoj plaći sredinom 2013. i osjetnog jednokratnog rasta minimalne plaće sredinom te godine $(6 \%)$, onda bi se moglo zaključiti da taj rast i novi zakon nisu doveli do značajnijeg rasta broja primatelja minimalne plaće, što potvrđuju kako ARS, tako i pokazatelji bazirani na granici od 105\% i 110\% minimalne plaće iz ADS-a. Iako bi to mogao biti jedan od pokazatelja da je tadašnji rast minimalne plaće bio usklađen s ekonomskim mogućnostima gospodarstva, za potpuniju ocjenu učinaka rasta minimalne plaće 2013. bilo bi potrebno ocijeniti učinke na zaposlenost, što zahtijeva složeniju analizu i detaljnije sektorske podatke, pa je takva ocjena izvan ambicija ovog rada.

S obzirom na umjerenu raširenost isplate minimalne plaće među zaposlenicima, kao i na ispodprosječnu stopu rizika siromaštva među primateljima minimalne plaće u odnosu na ukupno stanovništvo, ne začuđuje relativno mali udio zaposlenika na minimalnoj plaći i članova njihovih kućanstava među siromašnima. U 2014. godini tek su nešto više od $1 \%$ siromašnih činili primatelji minimalne plaće, a zajedno sa članovima svojih kućanstava oni su činili manje od 4\% siromašnih. Taj je udio ponešto smanjen u odnosu na prethodne dvije godine, posebno u odnosu na 2012. godinu kada je raširenost siromaštva među primateljima minimalne plaće bila osjetno veća, pa su blizu 7\% siromašnih činile osobe iz kućanstava u kojima žive primatelji minimalne plaće. ${ }^{12}$ Treba spomenuti da promjena stope raširenosti siromaštva među primateljima minimalne plaće ne pokazuje nužno cjelinu učinka promjene minimalne plaće na raširenost siromaštva. Naime, za cjelovitiju procjenu učinka promjene minimalne plaće trebali bi znati učinak na postojeću zaposlenost i na mogućnost zapošljavanja nezaposlenih i preko toga procijeniti je li rast minimalne plaće uz smanjenje siromaštva među primateljima minimalne plaće možda istovremeno u istoj ili većoj mjeri uzrokovao povećanje siromaštva među nezaposlenima. Podaci iz Tablice 5. pokazuju da 2014. nije došlo do povećanja stope siromaštva među nezapo-

\footnotetext{
${ }^{11}$ To potvrđuje da je zaokruživanje plaća u odgovorima imalo učinak na rezultate, a posebno u okolnostima kada se kod procjene u ARS-u za referentnu vrijednost koristi zakonska minimalnu plaću naknadno konvertirana u neto iznos. Osim što je to neprecizno zbog različitih poreznih obveza različitih radnika, to je dodatno usložnjeno zbog promjena u poreznom sustavu unutar godine (2012.). Kod ADS-a procjena je napravljena izravno na osnovi bruto plaća za cijelu godinu.

${ }^{12}$ Ovdje treba podsjetiti da podaci iz ADS-a predstavljaju uzorak i da bi pri svakom tumačenju opaženih proporcija trebalo imati na umu dase radi procjeni koje su predmetom statističke greške. Preciznost procjene opada sa smanjivanjem broja pojedinaca obuhvaćenih uzorkom. Tako, na primjer, kod procjene stope siromaštva kod zaposlenika na minimalnoj plaći od 17,2\% u 2014., uz 95\%-tnu pouzdanost možemo reći da se stvarna stopa siromaštva nalazi između 12,3\% i 22,2\%. Kod udjela siromašnih članova kućanstava primatelja minimalne plaće u ukupnom broju siromašnih od 3,9\% 95\%-tni interval pouzdanosti iznosi od 3,3\% do 4,5\%. Stoga manje opažene promjene iz godine u godinu opažene u uzorku ADS-a ne moraju nužno značiti stvarnu promjenu, koja bi se tek u rigoroznoj statističkoj analizi mogla potvrditi. Kako se ovaj rad fokusirao na uočavanje ključnih trendova u standardnom tipu analize, u njemu nisu objavljivani intervali pouzdanosti za svaki pokazatelj. Vrijedi ipak spomenuti da su svi pokazatelji iz ADS-a izračunati korištenjem populacijskih pondera koje je pripremio Državni zavod za statistiku. Zbog toga su izračunati pokazatelji siromaštva među zaposlenima i nezaposlenima identični službeno objavljenim podacima.
} 
slenima u odnosu na 2012., tako da takav kanal utjecaja vjerojatno nije bio izražen u promatranom razdoblju. ${ }^{13}$

Podaci ADS-a ukazuju da većina primatelja minimalne plaće nisu siromašni. Podaci prikazani u Tablici 6. pokazuju da više do $20 \%$ primatelja minimalne plaće živi u iznadprosječno dobrostojećim kućanstvima prema pokazatelju ekvivalentnog raspoloživog dohotka, odnosno da oni pripadaju u skupinu $40 \%$ stanovnika s najvišim dohocima. Jednu četvrtinu primatelja minimalne plaće mogli bi svrstati u srednju klasu jer pripadaju središnjem kvintilu u raspodjeli raspoloživog dohotka. Oko 35\% primatelja minimalne plaće pripada u drugi dohodovni kvintil, a za njih bi se moglo reći da žive u kućanstvima s ispodprosječnim dohotkom, ali još uvijek iznad granice siromaštva.

Tablica 6.

Zaposlenici na minimalnoj plaći prema dohodovnim kvintilima, 2014.

\begin{tabular}{lccc}
\hline & $\begin{array}{c}\text { Postotak } \\
\text { stanovništva }\end{array}$ & $\begin{array}{c}\text { Udio zaposlenika s } \\
\text { minimalnom plaćom u u } \\
\text { svakom kvintilu (\%) }\end{array}$ & $\begin{array}{c}\text { Raspodjela zaposleni- } \\
\text { ka na minimalnoj plaći } \\
\text { po kvintilima (\%) }\end{array}$ \\
\hline Najniži kvintil & 20 & 1,2 & 17,2 \\
\hline 2. kvintil & 20 & 2,5 & 35,0 \\
\hline Središnji kvintil & 20 & 1,8 & 25,0 \\
\hline 4. kvintil & 20 & 1,0 & 13,6 \\
\hline Najviši kvintil & 20 & 0,7 & 9,1 \\
\hline & & & 100,0 \\
\hline Ukupno & 100 & 1,4 & \\
\hline
\end{tabular}

Napomena: Dohodovni kvintili određeni su temeljem poretka osoba prema visini ekvivalentnog raspoloživog dohotka kućanstva, najniži kvintil sastoji se od 20 posto najsiromašnijih osoba, najviši kvintil od 20 posto najbogatijih osoba. Razmatra se raspodjela po kvintilima zaposlenika na minimalnoj plaći, točnije zaposlenika starijih od 18 godina koji rade puno radno vrijeme i primaju mjesečnu plaću manju od $105 \%$ zakonske minimalne plaće.

Izvor: Izračuni autora na temelju ADS-a 2015.

Pri razmatranju siromaštva među primateljima minimalne plaće vrijedi napomenuti da je iznos minimalne plaće veći od praga rizika od siromaštva za samca. Tako je minimalna plaća u neto iznosu 2014. godine iznosila između 2384 i 2414 kuna (ovisno o osobnom odbitku i stopi prireza u mjestu stanovanja), dok je mjesečni prag rizika od siromaštva za samca za tu godinu iznosio 2082 kune, odnosno 24979 kuna godišnje prema podacima iz ADS-a za 2015., koji se efektivno odnose na 2014. godinu. To znači da su primatelji minimalne plaće izloženi riziku siromaštva samo u slučajevima kada uz sebe u kućanstvu imaju uzdržavane članove, odnosno članove koji imaju manje prihode ili ih uopće nemaju. Tablica 7. pruža uvid u sastav kućanstva primatelja minimalne plaće, pri čemu su kućanstva podijeljena u tri skupine. U prvoj su kućanstva u kojima je primatelj minimalne plaće jedina zaposlena osoba, a što uključuje i samačka

\footnotetext{
${ }^{13}$ Navedeni zaključak osim na stopi siromaštva među nezaposlenima temeljimo i na podacima iz ADS-a o stopi nezaposlenosti za stanovništvo staro 18 godina. Ta je stopa2014. godine bila nešto niža nego 2012. godine, a manji je bio i procijenjeni ukupan broj nezaposlenih.
} 
kućanstva. U drugoj su kućanstva s dvoje zaposlenika na minimalnoj plaći, a u trećoj kućanstva u kojima uz jednu zaposlenu osobu s minimalnom plaćom postoji najmanje još jedna zaposlena osoba s plaćom iznad minimalne. ${ }^{14}$ Podaci pokazuju da oko $60 \%$ zaposlenika na minimalnoj plaći živi u kućanstvima u kojima uz njih postoji još najmanje jedna zaposlena osoba s većom plaćom. Tek nešto više od jedne četvrtine primatelja minimalne plaće živi u kućanstvima u kojim su oni jedine zaposlene osobe. Upravo takav sustav kućanstava može objasniti umjerenu raširenost siromaštva među primateljima minimalne plaće.

Tablica 7.

Kućanstava s članovima koji primaju minimalnu plaću, 2014.

\begin{tabular}{lccc}
\hline & $\begin{array}{c}\text { Udio u uku- } \\
\text { pnom broju } \\
\text { kućanstava } \\
(\%)\end{array}$ & $\begin{array}{c}\text { Raspodjela } \\
\text { zaposlenika na } \\
\text { minimalnoj plaći } \\
\text { po vrsti kućan- } \\
\text { stva }\end{array}$ & $\begin{array}{c}\text { Udio članovana } \\
\text { ka na minimalnoj } \\
\text { plaći u ukupnom } \\
\text { stanovništvu }\end{array}$ \\
\hline $\begin{array}{l}\text { Kućanstva u kojima je jedina zaposlena } \\
\text { osoba zaposlenik s minimalnom plaćom }\end{array}$ & 1,1 & 27,6 & 1,2 \\
\hline $\begin{array}{l}\text { Kućanstva s dvije zaposlene osobe, } \\
\text { oboje zaposlenici na minimalnoj plaći }\end{array}$ & 0,3 & 12,5 & 0,4 \\
\hline $\begin{array}{l}\text { Mješovita kućanstva (najmanje jedan } \\
\text { zaposlenik na minimalnoj plaći i najmanje } \\
\text { još jedna zaposlena osoba s plaćom } \\
\text { iznad minimalne) }\end{array}$ & 2,3 & 59,9 & 3,5 \\
\hline $\begin{array}{l}\text { UKUPNO } \\
\text { (kućanstva primatelja minimalne plaće) }\end{array}$ & 3,7 & 100,0 & 5,1 \\
\hline
\end{tabular}

Napomena: Pod zaposlenicima na minimalnoj plaći smatraju se samo oni čiji je najčešći status u aktivnosti u prošloj godini bio rad s punim radnim vremenom, a primali su manje od $105 \%$ zakonske minimalne plaće. Zaposlenici su definirani prema najčešćem statusu u aktivnosti.

Izvor: Vlastite procjene na osnovi ADS-a 2015.

\section{SIMULACIJA UČINAKA RASTA MINIMALNE PLAĆE NA SIROMAŠTVO I NEJEDNAKOST}

Poznavanje osnovnih karakteristika primatelja minimalne plaće može biti od velike pomoći prilikom procjene učinaka promjene visine minimalne plaće. Kako bi pokazali mogućnosti jedne takve konkretne procjene za Hrvatsku, u ovom smo se istraživanju usredotočili na podatke iz ADS-a i simuli- rali učinke značajnog jednokratnog rasta minimalne plaće na siromaštvo i nejednakost uz primjenu određenih pretpostavki o kretanju plaća, zaposlenosti i ukupnih dohodaka.

Polazi se od stanja 2014. godine, a na uzorak kućanstava i osoba iz ADS-a su primijenjene sljedeće pretpostavke:

a) zakonska minimalna plaća povećana je za $10 \%$

\footnotetext{
${ }^{14}$ Eventualno bi još mogla postojati kućanstva s tri i više zaposlenih osoba na minimalnoj plaći, ali takvih kućanstava nije bilo u uzorku kućanstava koja su anketirana u sklopu ADS-a 2015.
} 
b) svim zaposlenicima koji su imali plaću ispod prijašnje razine minimalne plaće plaća je povećana za $10 \%$

c) svim zaposlenicima čija je plaća bila između prijašnje i nove razine minimalne plaće, plaća je povećana na novu razinu minimalne plaće

d) primateljima minimalne plaće sada se smatraju svi zaposlenici u punom radnom vremenu čija je plaća manja od $105 \%$ nove minimalne plaće

e) nije došlo do prelijevanja rasta minimalne plaće na ostale plaće u gospodarstvu tako da su one ostale nepromijenjene

f) nepromijenjeni su i svi ostali dohoci stanovništva

g) zaposlenost je ostala nepromijenjena, odnosno nije došlo do otpuštanja zbog rasta minimalne plaće

h) uz gore navedene pretpostavke, izračunat je novi ukupan dohodak stanovništva kao i novi ekvivalentni dohodak stanovništva, te je na temelju toga izračunat novi prag rizika od siromaštva i novi izračuni stopa siromaštva

i) izračuni siromaštva napravljeni su i uz stari prag rizika od siromaštva (izračunat na osnovi ekvivalentnog dohotka prije rasta minimalne plaće), a u tom se slučaju govori o pragu rizika od siromaštva fiksiranom na razini iz 2014.

Vjerujemo da se na osnovi ovih pretpostavki može dobro ilustrirati mogući učinak rasta minimalne plaće na siromaštvo $u$ Hrvatskoj u jednom optimističnom scenariju. U stvarnosti bi se kod ovakvog rasta minimalne plaće mogli realizirati i negativ- ni učinci na zaposlenost, a s obzirom da se pretpostavlja izostanak takvog učinka, to znači da će simulacija ukazivati na moguću gornju granicu smanjivanja siromaštva i nejednakosti.

Rezultati simulacije prikazani su u Tablici 8. Oni prvo ukazuju da je učinak značajnog rasta minimalne plaće $(10 \%)$ na ukupno siromaštvo i u ovom povoljnom scenariju iznimno ograničen. Stopa rizika od siromaštva prije i nakon rasta minimalne plaće ostala je $20 \%$ (točnije, ona je smanjena za manje od 0,05 postotnih jedinica) ako se razmatra relativni prag rizika od siromaštva kako je to i uobičajeno u europskoj statističkoj praksi, a koji je izračunava kao 60\% medijana tekućeg ekvivalentnog dohotka. Rastom minimalne plaće poboljšana je pozicija primatelja minimalne plaće, pa je tako smanjena stopa rizika od siromaštva kod njih sa $17,2 \%$ na $15 \%$. No, rastom minimalne plaće, ujedno je povećan ukupan dohodak stanovništva pa je povećana i granica (prag) siromaštva zbog čega su siromašnima postali i neki koji ranije nisu bili siromašni, a čiji je dohodak ostao nepromijenjen. Zato je učinak na ukupnu stopu siromaštva ostao zanemariv. Čak i u slučaju da granicu siromaštva fiksiramo na ranijoj razini, učinak na ukupnu stopu siromaštva je mali, tako da je došlo do smanjenja s $20 \%$ na $19,8 \%$. Uz fiksiranu granicu siromaštva jedina je promjena kod primatelja minimalne plaće čija su kućanstva sada u manjoj mjeri siromašna.

No, s obzirom da u ukupnom broju siromašnih osoba primatelji minimalne plaće $i$ članovi njihovih kućanstava čine relativno mali dio, kako je to prethodno pokazano, učinak na ukupnu stopu siromaštva bio je malen. 
Tablica 8.

Rezultati simulacije učinaka jednokratnog rasta minimalne plaće za 10\% na siromaštvo i nejednakost

\begin{tabular}{|c|c|c|}
\hline & $\begin{array}{l}\text { Ostvareno } \\
2014 .\end{array}$ & $\begin{array}{c}\text { Simulacija } \\
\text { (nakon } 10 \%- \\
\text { tnog rasta MP-a) }\end{array}$ \\
\hline $\begin{array}{l}\text { Stopa rizika od siromaštva - uz relativni prag (\%) } \\
\text { (prag rizika od siromaštva je } 60 \% \text { medijana tekućeg ekvi- } \\
\text { valentnog dohotka) }\end{array}$ & 20,0 & 20,0 \\
\hline $\begin{array}{l}\text { Stopa rizika od siromaštva - uz fiksirani prag (\%) } \\
\text { (prag rizika od siromaštva fiksiran na razini ostvarenoj } \\
\text { 2014.) }\end{array}$ & 20,0 & 19,8 \\
\hline $\begin{array}{l}\text { Udio zaposlenika na minimalnoj plaći među zaposlenima } \\
\text { u punom radnom vremenu (\%) }\end{array}$ & 5,0 & 9,8 \\
\hline Prosječna starost zaposlenika na minimalnoj plaći (\%) & 36,7 & 37,9 \\
\hline Udio žena među zaposlenicima na minimalnoj plaći (\%) & 60,3 & 62,9 \\
\hline $\begin{array}{l}\text { Stopa siromaštva među zaposlenicima na minimalnoj pla- } \\
\text { ći }(\%)\end{array}$ & 17,2 & 15,0 \\
\hline -muškarci & 23,9 & 24,9 \\
\hline -žene & 12,8 & 9,1 \\
\hline $\begin{array}{l}\text { Jaz plaća između žena i muškaraca } \\
\text { (\% u kojem je prosječna plaća žena manje od plaće muš- } \\
\text { karaca) }\end{array}$ & 10,0 & 9,8 \\
\hline Ginijev koeficijent raspodjele ekvivalentnog dohotka & 31,4 & 31,3 \\
\hline $\begin{array}{l}\text { Ginijev koeficijent raspodjele bruto plaća } \\
\text { (zaposlenici s punim radnim vremenom) }\end{array}$ & 28,5 & 28,2 \\
\hline
\end{tabular}

Napomena: Pod zaposlenicima na minimalnoj plaći smatraju se zaposleni koji rade puno radno vrijeme i primaju manje od $105 \%$ zakonske, odnosno simulirane nove razine minimalne plaće.

Izvor: Vlastite procjene na osnovi ADS-a 2015.

Simulacija pokazuje da bi rast minimalne plaće za $10 \%$, uz sve drugo nepromijenjeno, udvostručio udio zaposlenika na minimalnoj plaći, s 5\% na gotovo $10 \%$. U takvoj situaciji postavlja se pitanje koliko je realna pretpostavka o izostanku učinka na zaposlenost. Može se zamisliti da bi poslodavci bili suočeni s osjetnim rastom troškova zaposlenih, ali i pritiskom na rast plaća ostalih zaposlenika koji bi zahtijevali da se primjereno većom plaćom nagrade $\mathrm{i}$ njihova radna mjesta koja pretpostavljeno zahtijevaju veće obrazovanje i veću odgovornost od radnih mjesta $\mathrm{s}$ minimalnom plaćom. No, za potrebe ove simulacije jednostavna pretpostavka o izostanku učinka na zaposlenost je dovoljna kako bi se uočila druga značajka distribucije plaća u Hrvatskoj. Naime, postoji velik broj zaposlenih koji primaju plaću tek nešto veću od minimalne, odnosno postoji velika gustoću plaća oko razine minimalne plaće. Zato usprkos umjerenoj raširenosti minimalne plaća (5-8\% koliko je procijenjeno u ovom radu na temelju ADS-a, odnosno ARS-a), treba očekivati da bi čak i umjereno dizanje minimalne plaće moglo utjecati na plaće velikog broja zaposlenika s niskim plaćama, a time i na osjetno veće troškove za poslodavce, u usporedbi sa slučajem da rast 
minimalne plaće pogađa relativno izolirani uski segment zaposlenih.

Rast minimalne plaće utjecat će na dobnu i spolnu strukturu primatelja minimalne plaće. Kao što je i ranije pokazano, mlađi zaposlenici češće primaju minimalnu plaću od starijih zaposlenika. No, oni su izgleda koncentrirani na samom donjem kraju distribucije plaće, jer simulacija pokazuje da povećanje minimalne plaće povećava i prosječnu starost primatelja (Tablica 8.), što znači da su novi primatelji, oni koji su to postali tek povećanjem minimalne plaće, ipak stariji od prijašnjih primatelja minimalne plaće. Simulacija pokazuje da rast minimalne plaće dovodi do povećanja udjela žena među primateljima minimalne plaće. Tako proizlazi da je među novim primateljima minimalne plaće, u odnosu na prijašnje primatelje minimalne plaće, iznadproporcionalno puno žena i starijih zaposlenika.

U pogledu siromaštva među primateljima minimalne plaće, posebno je zanimljiva njihova spolna struktura. Naime, 2014. je stopa siromaštva među muškim primateljima minimalne plaće bila gotovo dvostruko veća (24\%) nego među ženama (13\%). Primanja ostalih članova kućanstva i sastav kućanstva očito su uvjetovali situaciju u kojoj su muški primatelji minimalne plaće češće bili glavni pribavitelji dohotka za kućanstva, a zbog njihove niske plaće cijelo je kućanstvo ostalo siromašno. Nakon povećanja minimalne plaće stopa siromaštva kod muškaraca s minimalnom plaćom čak je i povećana (na 25\%), dok je kod žena ona osjetno smanjena (na 10\%). Očito je među novim primateljima minimalne plaće, kod muškaraca bilo više siromašnih nego među prijašnjim primateljima, dok je kod žena bilo manje siromašnih nego ranije.

Prema rezultatima simulacije, povećanje minimalne plaće je ograničeno utjecalo na nejednakost. Tako je prosječni jaz plaća između muškaraca i žena smanjen s $10 \%$ na $9,8 \%$. Kod primatelja minimalne plaće bilo je više žena, pa je rast minimalne plaće iznadproporcionalno obuhvatio plaće žena. Simulacija ukazuje da bi u slučaju pretpostavljenog rasta minimalne plaće Ginijev koeficijent raspodjele dohotka bio tek vrlo blago smanjen (s 31,4 na 31,3), a ponešto bi bio smanjen i Ginijev koeficijent raspodjele bruto plaća (s 28,5 na 28,2). Može se napomenuti da bi u realnim okolnostima trebalo očekivati da paralelno s rastom minimalne plaće dođe $\mathrm{i}$ do rasta drugih plaća $\mathrm{i}$ drugih dohodaka, pa bi učinak na nejednakost bio manji.

\section{ZAKLJUČAK}

Minimalna plaća je važan instrument regulacije tržišta rada. Istraživanje učinaka takve regulacije može pomoći u dizajnu politike minimalne plaće kojom se jačaju pozitivne, a izbjegavaju negativne strane. U ovom je radu fokus istraživanja bio na karakteristikama primatelja minimalne plaće i njihovih kućanstava u Hrvatskoj, što bi moglo pomoći u osmišljavanju takve politike. U usporedbi s dosadašnjim istraživanjima za Hrvatsku, u radu su prikazani noviji podaci o socio-ekonomskim karakteristikama primatelja minimalne plaće na temelju Ankete o radnoj snazi i razmotrene promjene koje su se dogodile između 2007. i 2014. godine, dok se po prvi put u domaćoj literaturi analizira materijalni položaj i siromaštvo među primateljima minimalne plaće na temelju podataka iz Ankete o dohotku stanovništva.

Rezultati pokazuju da je nakon donošenja Zakona o minimalnoj plaći 2008. godini došlo do povećanja udjela zaposlenika na minimalnoj plaći, a što se ponovno dogodilo nakon donošenja novog Zakona o minimalnoj plaći 2013. No, ukupno gledano, udio zaposlenika na minimalnoj plaći 
je umjeren i on je 2014. godine iznosio oko $8 \%$ prema podacima iz ARS-a, odnosno $5 \%$ prema podacima ADS-a.

Rezultati na temelju ARS-a pokazuju da u strukturi zaposlenika na minimalnoj plaći dominiraju žene, mlađe i slabije obrazovane osobe, zaposleni s ugovorom na određeno vrijeme te zaposleni u malim poduzećima. No, posljednjih godina raste udio mlađih i visokoobrazovanih radnika među primateljima minimalne plaće, a smanjuje se udio žena. Smanjenje udjela žena smatra se posljedicom smanjenja zaposlenosti u sektorima s niskim plaćama u kojima su većinom zaposlena žene. Povećani udio obrazovanih i mladih mogao bi biti povezan s aktivnom politikom zapošljavanja, ponajprije SOR-om, gdje se upravo takav profil osoba zapošljava uz niske plaće, odnosno naknade.

Analiza materijalnog položaja kućanstava zaposlenika na minimalnoj plaći na temelju ADS-a pokazuje da je siromaštvo među primateljima minimalne plaće znatno veće nego kod ostalih zaposlenika, ali i manje od hrvatskog prosjeka. U 2014. su tek nešto više od $1 \%$ svih siromašnih činili primatelji minimalne plaće, a zajedno sa članovima svojih kućanstava oni su činili manje od 4\% siromašnih. Malo više od polovice primatelja minimalne plaće živi u kućanstvima koja pripadaju u 40\% najsiromašnijih u Hrvatskoj, ali više od 20\% primatelja živi u kućanstvima čiji ih dohoci klasificiraju među 40\% najbogatijih u Hrvatskoj. Prag rizika od siromaštva u Hrvatskoj je niži od minimalne plaće, tako da samci primatelji minimalne plaće ne ulaze u skupinu siromašnih. Stoga se još jednom potvrđuje da rad za minimalnu plaću ne znači nužno život u siromaštvu, već siromaštvo u tom slučaju ovisi o materijalnom stanju cijelog kućanstva, odnosno o tome mora li primatelj minimalne plaće uzdržavati druge osobe ili ne.
Rezultati simulacije rasta minimalne plaće za $10 \%$ uz nepromijenjene sve druge okolnosti u pogledu zaposlenosti, dohodaka i plaća ukazuju na male učinke na ukupno siromaštvo i nejednakost u Hrvatskoj. Razlog tome je prije svega relativno mali udio primatelja minimalne plaće među siromašnima. Postoje druge kategorije stanovništva čiji su dohoci niži od dohodaka zaposlenih na minimalnoj plaći, a koji su češće siromašni i na koje promjene u politici minimalne plaće neće utjecati. Temeljem ovih simulacija može se zaključiti da za značajnije učinke na siromaštvo treba koristiti druge politike koje izravnije dopiru do siromašnih, dok politika minimalne plaće u tom pogledu ima ograničene dosege.

\section{LITERATURA}

Addison, J. T., Blackburn, M. L., \& Cotti, C. D. (2009). Do minimum wages raise employment? Evidence from the US Retail-trade sector. Labour Economics, 16(4), 397-408. https://doi.org/10.1016/j.labeco.2008.12.007

Allegretto, S., Dube, A., Reich M., \& Zipperer B. (2013). Credible research designs for minimum wage studies. IRLE Working Paper No. 148-13. Dostupno na http://irle.berkeley.edu/ workingpapers/148-13.pdf

Banyuls, J., Grimshaw, D., Nestić, D., \& Neumann, L. (2013). Wage compression among sales assistants? Pay bargaining and ripple effects in the retail sector. In D. Grimshaw (Ed.), Minimum wages, pay equity and comparative industrial relations (pp. 194-224). New York: Routledge.

Blažević, S. (2012). Socio-ekonomski učinci minimalne plaće (doktorska disertacija). Ekonomski fakultet, Split.

Bosch, G., Nestić, D., \& Neumann, L. (2013). Minimum wages and collective bargaining in the construction industry. In D. Grimshaw (Ed.), Minimum wages, pay equity and comparative industrial relations (pp. 168-193). New York: Routledge. 
Brown, C., Gilroy, C., \& Kohen, A. (1982). The effect of the minimum wage on employment and unemployment. Journal of Economic Literature, 20(2), 487-528. https://www.jstor.org/ stable/2724487

Bruttel, O., Baumann, A., \& Dütsch, M. (2017). The new German statutory minimum wage in comparative perspective: Employment effects and other adjustment channels. European Journal of Industrial Relations, 24(2), 145-162. https://doi.org/10.1177/0959680117718661

Burauel P., Caliendo, M., Fedorets, A., Grabka, M. M., Schröder C., Schupp J., \& Wittbrodt L. (2017). Minimum wage not yet for everyone: On the compensation of eligible workers before and after the minimum wage reform from the perspective of employee. DIW Economic Bulletin, (49), 509-522. Dostupno na https://www.diw.de/sixcms/detail. php?id=diw_01.c.572808.de

Card, D., \& Krueger, A. B. (1994). Minimum wages and employment: A case study of the fast-food industry in New Jersey and Pennsylvania. The American Economic Review, 84(4), 772-793. https://www.jstor.org/stable/2118030

Carević, M., Kiš, P., \& Kuhta, F. (2008). Minimum wages as an obstacle to the free provision of services. Croatian yearbook of European law \& policy, 4(4), 75-100. https://hrcak.srce. $\mathrm{hr} / 28576$

Doucouliagos, H., \& Stanley, T. D. (2009). Publication selection bias in minimum-wage research? A meta-regression analysis. British Journal of Industrial Relations, 47(2), 406-428. https://doi.org/10.1111/j.14678543.2009.00723.x

Državni zavod za statistiku. (2013). Anketa o radnoj snazi. Metodološke upute 71. Zagreb: Državni zavod za statistiku.

Državni zavod za statistiku. (2017). Statistički ljetopis 2017. Zagreb: Državni zavod za statistiku.

Dube, A., Lester, T. W., \& Reich, M. (2010). Minimum wage effects across state borders: Estimates using contiguous counties. Review of Economics and Statistics, 92(4), 945-964. https://doi.org/10.1162/REST_a_00039
Eurostat. (2018). Minimum wage statistics. Dostupno na http://ec.europa.eu/eurostat/statisticsexplained/index.php/Minimum_wage_statistics.

Giuliano, L. (2013). Minimum wage effects on employment, substitution, and the teenage labor supply: Evidence from personnel data. Journal of Labor Economics, 31(1), 155-194. https://doi.org/10.1086/666921

Grgurev, I., \& Vukorepa, I. (2013). Minimum wage as a tool in the fight against poverty: Croatian labour law perspective. In G. Löschnigg (Ed.), Staatliche Eingriffeindas System der Mindestentgelte im internationalen Vergleich (pp. 280-308). Wien: Verlag des ÖGB.

Heise, A. (2017). Reconciling facts with fiction: Minimum wages in a post-Keynesian perspective. Discussion Papers, No. 64. Hamburg: Zentrum für Ökonomische und Soziologische Studien.

Hrvatski zavod za zapošljavanje. (2016). Vanjska evaluacija mjera aktivne politike tržišta rada 2010.-2013. Sumarno evaluacijsko izvješće. Zagreb: HZZ.

Mrnjavac, Ž., \& Blažević, S. (2014). Is minimum wage a good policy for poor workers in Croatia?. Management : journal of contemporary management issues. 19(1), 17-43. https://hrcak.srce.hr/124607

Nestić, D. (2009). Plaće u Hrvatskoj: trendovi, problemi i očekivanja, U V. Franičević, V. Puljiz (ur.), Rad u Hrvatskoj: Pred izazovima budućnosti (str. 165-195). Zagreb: Centar za demokraciju i pravo Miko Tripalo; Pravni fakultet Sveučilišta u Zagrebu.

Nestić, D. (2010). Croatia: Moving towards a more active minimum wage policy. In D. Vaughan-Whitehead (Ed.), The Minimum Wage Revisited in the Enlarged EU (pp. 85-112). Chaterham: Edward Elgar; Geneva: International Labour Office.

Nestić, D., \& Rašić Bakarić, I. (2010). Minimum wage systems and changing industrial relations in Europe - National Report Croatia. Dostupno na http://www.eizg.hr/en-US/Minimum-Wage-Systems-and-Changing-Industrial-Relations-National-Report-Croatia-634.aspx 
Nestić D., Babić, Z., \& Blažević Burić, S. (2018). Minimum wage in Croatia: Sectoral and regional perspectives. Ekonomska istaživanja, 31. https://doi.org/10.1080/133167 7X.2018.1473787

Neumark, D., \& Wascher, W. (1992). Evidence on employment effects of minimum wages and subminimum wage provisions: Panel Data on state minimum wage laws. Industrial and Labor Relations Review, 46(1), 55-81. https:// doi.org/10.1177/001979399204600105

Neumark, D., \& Wascher, W. (2006). Minimum wages and employment: A review of evidence from the new minimum wage research.
National Bureau of Economic Research Working Paper 12663. Cambridge, MA: National Bureau of Economic Research. Dostupno na http://www.nber.org/papers/w12663

Neumark, D., \& Wascher, W. (2008). Minimum wages. Cambridge: The MIT Press.

Rožman, K. (2009). Zakon o minimalnoj plaći dvojbe u načinu utvrđivanja visine minimalne plaće. Radno pravo, (6), 19-25.

Wolfson, P., \& Belman, D (2014). What does the minimum wage do? Kalamazoo, MI: W. E. Upjohn Institute for Employment Research. 


\title{
Summary
}

\section{MINIMUM WAGE EARNERS AND POVERTY IN CROATIA}

\author{
Danijel Nestić \\ The Institute of Economics, Zagreb \\ Croatia \\ Sanja Blažević Burić \\ The Faculty of Economics and Tourism "Dr. Mijo Mirković" \\ Juraj Dobrila University of Pula \\ Croatia
}

This paper describes the key socio-economic characteristics of minimum wage earners in Croatia, estimates their material position and household poverty, and presents the results of a simulation of a minimum wage increase on poverty and inequality. The findings are based on the Labour Force Survey (LFS) and Survey of Income and Living Conditions (SILC) data. The LFS-based estimate shows a gradual increase in the number of minimum wage workers between 2007 and 2014, particularly among young people and highly educated workers, as well as a reduction in the proportion of women. Sectors with the highest incidence of minimum wages include: manufacturing industry; retail and wholesale trades; construction; accommodation and food preparation and service activities. The SILC-based estimate shows that the at-risk-of-poverty rate among minimum wage earners is lower than the rate for the Croatian population as a whole. Minimum wage earners account for slightly more than $1 \%$ of the poor. Simulation results for a minimum wage increase indicate its limited effects on poverty and income inequality.

Keywords: minimum wage, minimum wage earners, poverty, Croatia. 